\title{
Observations of water masses and circulation with focus on the Eurasian Basin of the Arctic Ocean from the 1990s to the late 2000s
}

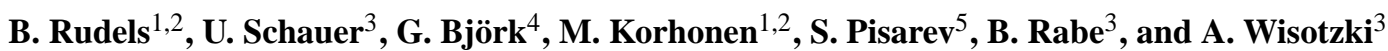 \\ ${ }^{1}$ Department of Physics, University of Helsinki, P.O. Box 64, 00014, Helsinki, Finland \\ ${ }^{2}$ Finnish Meteorological Institute, Erik Palmenin aukio 1, P.O. Box 503, 00101 Helsinki, Finland \\ ${ }^{3}$ Alfred Wegener Institute for Polar and Marine Research, P.O. Box 120161, 27515 Bremerhaven, Germany \\ ${ }^{4}$ Department of Earth Sciences, University of Gothenburg, Box 460, 40530 Gothenburg, Sweden \\ ${ }^{5}$ Shirshov Institute of Oceanology, 36 Nakhimovsky Prospect, Moscow 117997, Russia
}

Correspondence to: B. Rudels (bert.rudels@ fmi.fi)

Received: 5 July 2012 - Published in Ocean Sci. Discuss.: 8 August 2012

Revised: 15 January 2013 - Accepted: 28 January 2013 - Published: 19 February 2013

\begin{abstract}
The circulation and water mass properties in the Eurasian Basin are discussed based on a review of previous research and an examination of observations made in recent years within, or parallel to, DAMOCLES (Developing Arctic Modeling and Observational Capabilities for Long-term Environmental Studies). The discussion is strongly biased towards observations made from icebreakers and particularly from the cruise with R/V Polarstern 2007 during the International Polar Year (IPY). Focus is on the Barents Sea inflow branch and its mixing with the Fram Strait inflow branch. It is proposed that the Barents Sea branch contributes not just intermediate water but also most of the water to the Atlantic layer in the Amundsen Basin and also in the Makarov and Canada basins. Only occasionally would high temperature pulses originating from the Fram Strait branch penetrate along the Laptev Sea slope across the Gakkel Ridge into the Amundsen Basin. Interactions between the Barents Sea and the Fram Strait branches lead to formation of intrusive layers, in the Atlantic layer and in the intermediate waters. The intrusion characteristics found downstream, north of the Laptev Sea are similar to those observed in the northern Nansen Basin and over the Gakkel Ridge, suggesting a flow from the Laptev Sea towards Fram Strait. The formation mechanisms for the intrusions at the continental slope, or in the interior of the basins if they are reformed there, have not been identified. The temperature of the deep water of the Eurasian Basin has increased in the last $10 \mathrm{yr}$ rather more than expected from geothermal heating. That geothermal heating does influence the deep water column was obvi-
\end{abstract}

ous from 2007 Polarstern observations made close to a hydrothermal vent in the Gakkel Ridge, where the temperature minimum usually found above the 600-800 m thick homogenous bottom layer was absent. However, heat entrained from the Atlantic water into descending, saline boundary plumes may also contribute to the warming of the deeper layers.

\section{Introduction}

Recent studies of the Arctic Ocean circulation have focused on three discoveries, or rediscoveries, occurring in the $1980 \mathrm{~s}$ and 1990s. (1) The realisation that the inflow of Atlantic water from the Norwegian Sea over the Barents Sea to the Arctic Ocean is of comparable magnitude as the inflow of Atlantic water taking place in Fram Strait (Rudels, 1987; Blindheim, 1989). (2) The shelf contribution to the formation of the halocline does not just involve the creation of dense water by brine rejection that eventually penetrates into the deep basin water column but also the outflow of low salinity shelf water that overruns the winter mixed layer in the Nansen Basin, transforming it into a halocline water mass (Rudels et al., 1996). (3) The inflow of anomalously warm Atlantic water to the Arctic Ocean in the late 1980s and early 1990s (Quadfasel et al., 1991), and the relocation of the upper low salinity surface water from a large part of the Amundsen Basin into the Makarov Basin and even into the Canada Basin, and the shift of the surface front between the Atlantic and the Pacific derived waters from the Lomonosov Ridge to the Mendeleev 
Ridge (Carmack et al., 1995; Morison et al., 1998; Steele and Boyd, 1998). The present study reviews how these findings have guided recent research and in particular the oceanography work from icebreakers conducted within DAMOCLES (Developing Arctic Modeling and Observational Capabilities for Long-term Environmental Studies). It also describes how observations made in the late part of the 2000s have improved our understanding of the Arctic Ocean processes and circulation.

\section{The Barents Sea inflow branch}

\subsection{The inflow over the Barents Sea}

The assumption that much, if not most, of the water that enters the Arctic Ocean from the Nordic seas passes through the Barents Sea is not new. It was the view of Petermann in 1870 (cited by Nansen, 1902). Nansen, in the same foot note, writes that this was also his own view before he had made the expedition with Fram. After the Fram expedition he concluded that a submarine barrier prevented most of the water that enters the Barents Sea to pass eastward beyond Franz Josef Land and adopted the view that most of the water from the Nordic seas present in the Arctic Ocean, especially the warm, $>0{ }^{\circ} \mathrm{C}$ "Atlantic" water, entered through Fram Strait (Nansen, 1902, p. 335). However, he still considered the possibility that the saline bottom water observed in the Arctic Ocean during the Fram expedition could be formed by ice formation and brine rejection on the Barents Sea (Nansen, 1906). Only after observations north of Svalbard from his sailing vessel Veslem $\phi y$ in 1912 did he become convinced that the deep water salinities measured from Fram were too high and that also the deep water entered the Arctic Ocean from the Greenland Sea through Fram Strait (Nansen, 1915). Nansen's revised view then became the accepted one for the coming generations of Arctic oceanographers, and the Barents Sea inflow was often neglected as is seen from the list of Arctic Ocean volume budgets given in Coachman and Aagaard (1974). However, some budget estimates show the inflows through Fram Strait and the Barents Sea to be of comparable magnitude (e.g. Fletcher, 1965; Nikiferov and Sphaiker, 1980).

The importance of the Fram Strait inflow was really brought into focus when the results from the first direct current measurements in the West Spitsbergen Current at $79^{\circ} \mathrm{N}$ were reported and indicated a northward transport of almost $8 \mathrm{~Sv}\left(1 \mathrm{~Sv}=10^{6} \mathrm{~m}^{3} \mathrm{~s}^{-1}\right)$ (Aagaard et al., 1973). In the mass, heat and salt budgets proposed by Aagaard and Greisman (1975), the exchanges through Fram Strait were assumed to balance with a northward flow of $7.1 \mathrm{~Sv}$ of Atlantic water and a southward flow of $1.8 \mathrm{~Sv}$ of low salinity polar water and 5.3 Sv of returning, cooled and modified Atlantic water (Arctic Atlantic water - AAW). By contrast the inflow over the Barents Sea was estimated at $0.7 \mathrm{~Sv}, 10 \%$ of the north- ward flow in the West Spitsbergen Current. The Fram Strait transport estimate given by Aagaard and Greisman did not include any deep water exchange.

The importance of the Barents Sea inflow to the Arctic Ocean was reintroduced in the late 1980s, when Rudels (1987) estimated the transport over the Barents Sea by formulating a heat budget for the Atlantic water and for the Norwegian Coastal Current water entering from the Norwegian Sea. These waters mainly leave the Barents Sea through the passage between Novaya Zemlya and Franz Josef Land, continuing down the St. Anna Trough, but also flow north in the Victoria Channel, and the coastal water may pass through the Kara Gate south of Novaya Zemlya. However, Rudels assumed that a large fraction, two-thirds, of the Atlantic water recirculated in the Hopen Deep and returned as cooler water in the Bear Island Channel to the Norwegian Sea. The inflow to the Arctic Ocean was estimated at 1.2 Sv, of which the Norwegian Coastal Current supplied $0.8 \mathrm{~Sv}$. Blindheim (1989) obtained from 3 weeks of direct current measurements a similar inflow from the Norwegian Sea but found that the recirculation was considerably smaller than Rudels (1987) had assumed and estimated a net inflow of 1.8-1.9 Sv. This included the contribution from the Norwegian Coastal Current, which was not given separately by Blindheim but was later estimated to $0.8 \mathrm{~Sv}$ by Aagaard and Carmack (1989) based on Blindheim's work.

Current measurements made continuously since 1997 between Nordkapp and Bjørnøya, the Barents Sea Opening, have largely confirmed Blindheim's estimate, but also revealed large seasonal and monthly variability of the transports (Ingvaldsen et al., 2004a, b). Recent direct velocity observations of the Norwegian Coastal Current have, however, shown that this transport is $\sim 1.8 \mathrm{~Sv}$, considerably larger than previously estimated (Skagseth et al., 2011). Only twice, 1991-1992 and 2008-2009, has a current meter array been deployed and recovered in the passage between Novaya Zemlya and Franz Josef Land, the expected main pathway for the Barents Sea inflow to the Arctic Ocean. The observed transports ( 2 Sv) for the 1991-1992 array (Loeng et al., 1993; Schauer et al., 2002a) agree well with the inflow at the Barents Sea Opening found by Blindheim (1989). The data from the 2008-2009 array are not yet available.

\subsection{The impact on the Arctic Ocean water column}

The influence of the Barents Sea branch on the Arctic Ocean water column was recognised by Rudels et al. (1994) from the hydrographic observations in the Nansen and Amundsen basins obtained on the Arctic Ocean-91 expedition with IB Oden. The presence of inversions and intrusions in the water column, in the warm Atlantic layer as well as in the intermediate layers below, was interpreted as results of interactions between two inflow branches: a warm and saline Fram Strait inflow branch and a cooler and fresher Barents 
Sea inflow branch, taking place as they meet on the continental slope north of the Kara Sea. The Oden stations were located away from the slope and west of the area, where the branches were expected to meet. However, the observations indicated that the fraction of Barents Sea branch water in the water column increased towards the Lomonosov Ridge. This implied that part of the Barents Sea branch water, and most likely also much of the Fram Strait branch water encountered in the interior of the Eurasian Basin away from the continental slope, flows towards Fram Strait. Such a flow pattern requires at least a partial turning of the two branches north of the Laptev Sea before they reach the Lomonosov Ridge, causing much of the Atlantic inflow to remain in the Eurasian Basin.

Subsequent observations north of the Laptev Sea confirmed the presence of less saline Barents Sea branch water at the slope (Schauer et al., 1997), and strong interleaving between the two branches was observed north of Severnaya Zemlya on the shoreward side of the Fram Strait branch in 1995 (Rudels et al., 2000a). Farther offshore the temperature maximum of the Fram Strait branch was unaffected by the intrusions. North of the Laptev Sea, the temperature of the Atlantic layer was considerably lower than north of the Barents Sea (Schauer et al., 1997) and north of the eastern Kara Sea (Rudels et al., 2000a; Walsh et al., 2007). However, large differences were observed between profiles obtained at stations with multiple casts, indicating large spatial (drift of the ship), but perhaps also temporal, variability as the water column advects along the slope (Rudels et al., 2000a). Cold, low salinity lenses were observed at intermediate depth in the Makarov Basin in 1994 (e.g. Swift et al., 1997), and water with similar characteristics was found at the sill $(1600 \mathrm{~m})$ of the Lomonosov Ridge close to the Siberian continental slope (Rudels et al., 2000a). An inflow of Barents Sea branch water across the Lomonosov Ridge would largely explain the presence of these cold, low salinity lenses in the Amerasian Basin (Swift et al., 1997). Barents Sea branch water has lately been almost exclusively associated with this low salinity, cold, intermediate water mass. This is a simplification. The Barents Sea branch comprises a large range of densities and contributes significantly to the warm Atlantic core in the Amerasian Basin, usually associated with the Fram Strait branch, as well as partly supplies water to the lower halocline (Rudels et al., 2004; Aksenov et al., 2011).

\section{Changes in the Fram Strait inflow branch}

The Atlantic water entering through Fram Strait and the variability of the Fram Strait inflow branch have received considerable attention. Fram Strait is the only deep passage connecting the Arctic Ocean with the Nordic seas and across the Greenland-Scotland Ridge to the North Atlantic. It has long been considered the most important passage for oceanic heat to the Arctic Ocean, and it is the main exit for the Arctic sea ice and the only opening allowing exchanges of intermediate and deep waters. The estimates of the Atlantic water transport into the Arctic Ocean have varied from 2-3 Sv to the high value of $7 \mathrm{~Sv}$ in the 1970s (Aagaard and Greisman, 1975) and then again to a low value of $1 \mathrm{~Sv}$ in the late 1980s (e.g. Aagaard and Carmack, 1989) after the discovery of the large recirculation of Atlantic water in Fram Strait (Quadfasel et al., 1987; Rudels, 1987; Bourke et al., 1988).

After regular monitoring of the exchanges in Fram Strait began with VEINS (Variability of Exchanges in the Northern Seas) in 1997, the northward transport of Atlantic water in the West Spitsbergen Current has been found to range between 3-5 Sv, with large variations but no decisive trend (Schauer et al., 2004, 2008; Rudels et al., 2008; Schauer and Beszczynska-Möller, 2009; Beszczynska-Möller et al., 2012). The velocities observed from the array are largely barotropic, and the total northward and southward transports are 2-3 times larger than the transport of Atlantic water. A substantial fraction of the exchanges is also related to the presence of barotropic eddies in the strait as well as the overall recirculation. An increased northward flow in the West Spitsbergen Current is often compensated by larger recirculation in the strait and warmer Atlantic water in the East Greenland Current. Part of the inflow thus recirculates within the strait, and about 2-3 Sv contribute to the eastward boundary current along the Eurasian continental slope (Schauer et al., 2008).

In 1990 anomalously warm Atlantic water was observed at the continental slope of the Eurasian Basin (Quadfasel et al., 1991). It was the first observation of a warmer, and likely also stronger, inflow taking place in the late 1980s and early 1990s. The warmer water could be followed across the Lomonosov Ridge into the Makarov and Canada basins (Carmack et al., 1995; McLaughlin et al., 1996). The advection of the warmer Atlantic water then offered an opportunity to determine the pathways of the Atlantic water in the Arctic Ocean. Anomalously high temperatures were observed in the Atlantic layer west of the Chukchi Borderland in 1998 (Shimada et al., 2004), but its subsequent movement around the Chukchi Borderland or between the Chukchi Borderland and the continental slope appeared to be much slower than the passage from Fram Strait to the Chukchi Sea slope. It is also not obvious which route, around the Chukchi Borderland or along the slope, is the most important one.

Low Atlantic water temperatures were reported from the Alpha Ridge (Falkner et al., 2005), and on the temperature section across the Amerasian Basin taken by IB Oden on the Beringia expedition in 2005, the lowest Atlantic layer temperatures were observed at the Alpha Ridge. Similar low Atlantic layer temperatures were also observed over the Alpha Ridge on the Polarstern cruise in 2007 (Fig. 1). This suggests that older, and colder, Atlantic water has been displaced northward from the southern Canada Basin and is entering the northern Canada Basin from the North American continental slope along the Alpha Ridge. 



Fig. 1. Upper panel and left map: sections of potential temperature and salinity from Alaska to the Lomonosov Ridge taken by IB Oden in 2005. Centre panel and centre map: sections of potential temperature and salinity between the Alpha Ridge and the Lomonosov Ridge taken by R/V Polarstern 2007 (western section). Lower panel and right map: sections of potential temperature and salinity between the Alpha Ridge and the Lomonosov Ridge taken by R/V Polarstern 2007 (eastern section). Figures are created using Ocean Data View (Schlitzer, 2012).

The temperature of the Atlantic water on the Makarov Basin side of the Lomonosov Ridge had increased by 2004 (Kikuchi et al., 2005), and the observations from Oden 2005 indicated that the temperatures at the Makarov Basin side were as high, or even higher than, on the Amundsen Basin side (see Figs. 1 and 13). This implies, first, that a part of the warm Atlantic water pulse had entered the Makarov Basin at the Mendeleev Ridge, circulated around the basin in about $10 \mathrm{yr}$ and was now returning towards Siberia along the Lomonosov Ridge, and, second, the Atlantic water on the Amundsen Basin side had been replaced by colder Atlantic water, presumably from a later, colder inflow event. A reduction in the Atlantic water inflow temperatures in Fram Strait was observed between 1984 and 1997 (Rudels et al., 2000b), and the arrival of colder Atlantic water at the NA-
BOS (Nansen-Amundsen Basin Observational System) stations and moorings north of the Laptev Sea was detected in 2003 (Dmitrenko et al., 2005).

Since 1997 the VEINS/ASOF/DAMOCLES mooring array (ASOF - Arctic/Subarctic Ocean Fluxes) in Fram Strait has revealed several pulses of warmer Atlantic water passing into the Arctic Ocean, and there has been a general trend towards higher temperature, having a maximum in 2006 and slightly decreasing thereafter (Hughes et al., 2011). The higher temperatures observed at the NABOS moorings north of the Laptev Sea after 2003 are likely related to the arrival of these pulses, and the time evolution of the Atlantic water at different positions has been documented and summarised by Dmitrenko et al. (2005) and Polyakov et al. $(2005,2011)$. 


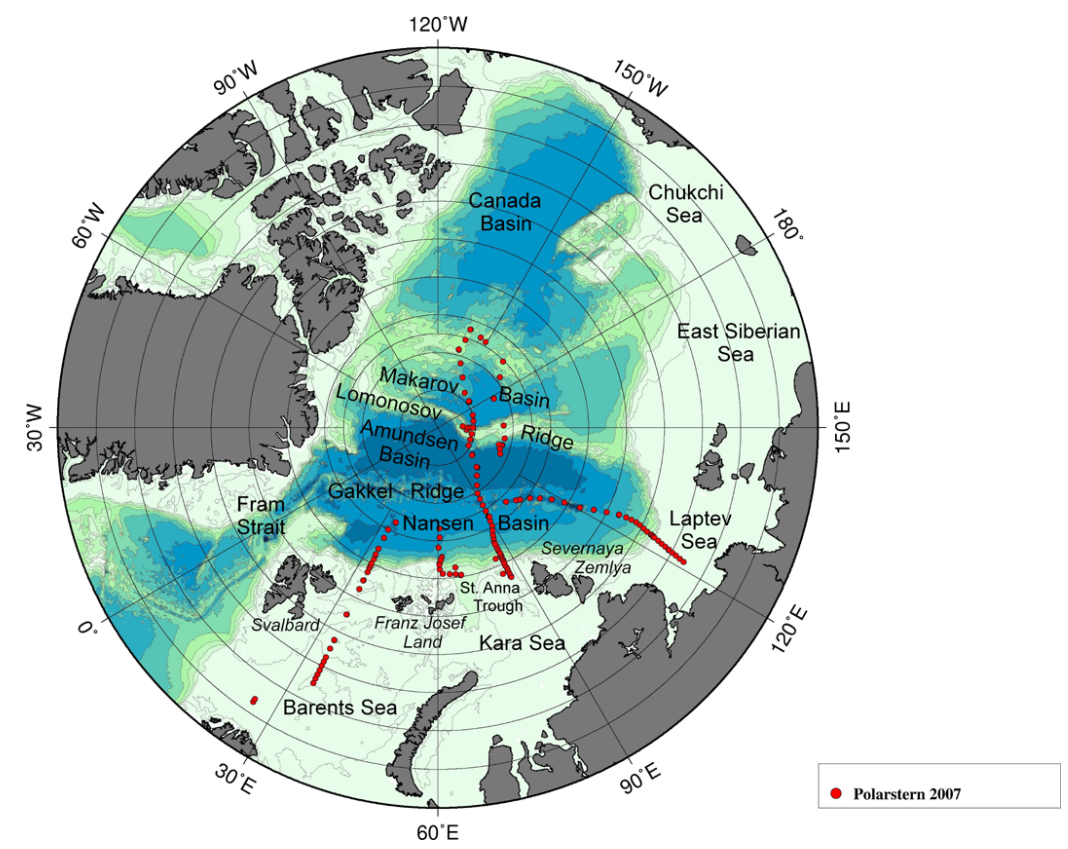

Fig. 2a. The station positions on the SPACE cruise 2007 with R/V Polarstern.

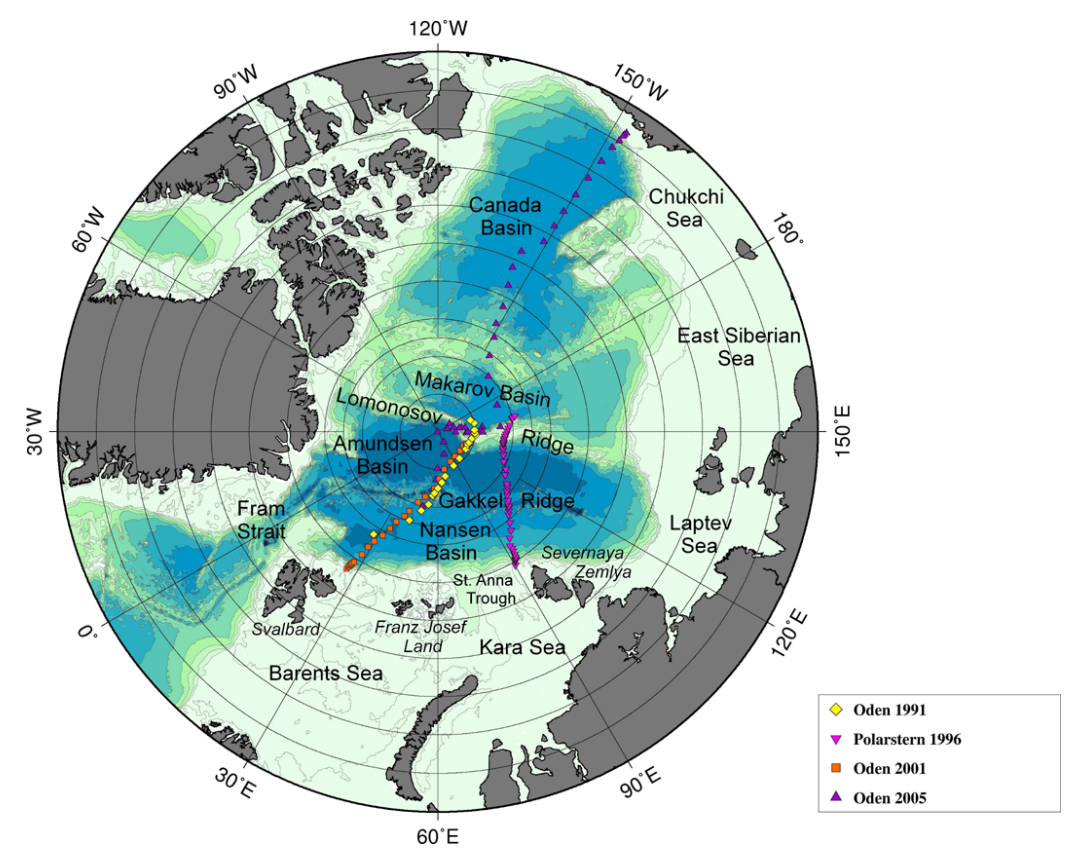

Fig. 2b. The positions of the stations from Oden 1991, Polarstern 1996, Oden 2001 and Oden 2005 used in this work.

The upstream sources of the warm Atlantic inflow pulses have also been investigated. Much of the higher temperature relates to higher air temperature and less cooling in the Norwegian Sea connected with the positive NAO (North Atlantic Oscillation) state prevailing in the late 1980s and early 1990s (Karcher et al., 2003). However, some changes can be traced farther south (Holliday et al., 2008). It has been proposed that the strength of the northward flow of Atlantic water across the Greenland-Scotland Ridge is related to the wind stress curl at $55^{\circ} \mathrm{N}$ (Orvik and Skagseth, 2003), and it has also been noticed that the subpolar gyre south of the Greenland-Scotland Ridge has a two-mode structure. Either a larger part of the water is brought northward into Nordic seas, or more is kept in the gyre and carried westward into the Irminger Sea and ultimately into the Labrador Sea (Hátun et al., 2005). Both these processes, related to the atmospheric 

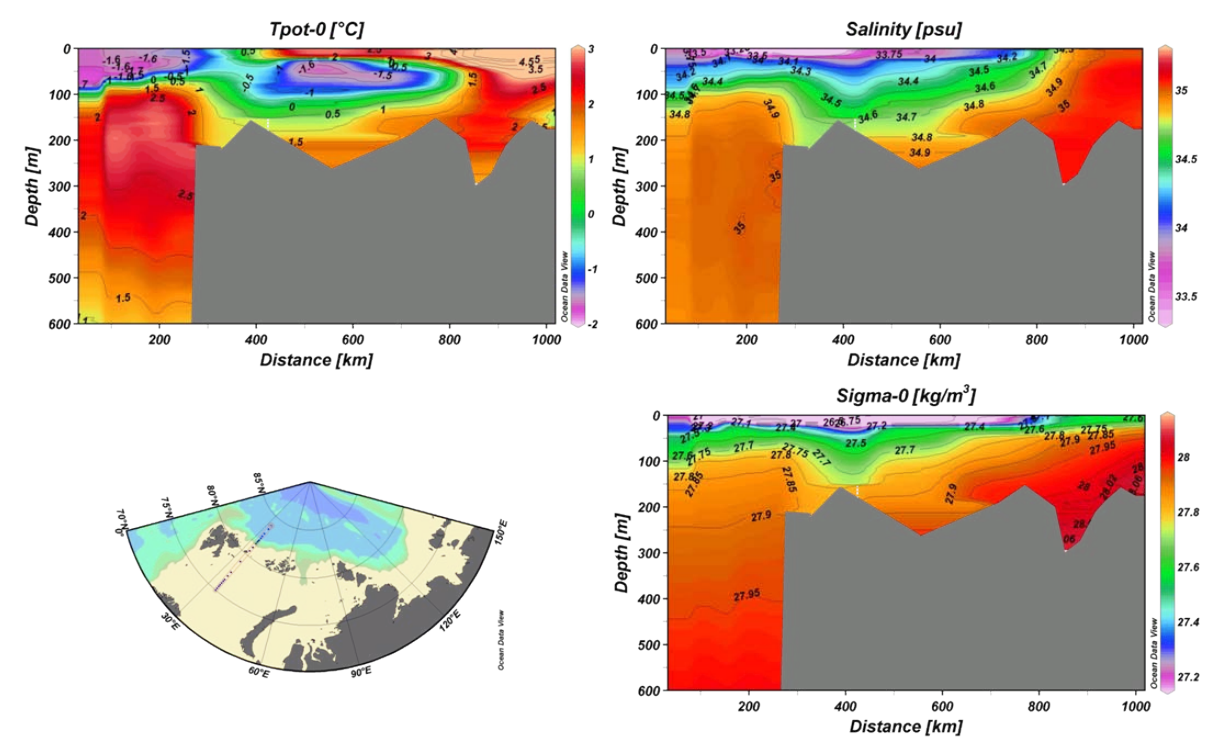

Fig. 3 . Potential temperature, salinity and potential density sections from the SPACE transect along $3^{\circ} \mathrm{E}$ from the Barents Sea into the Nansen Basin.

circulation and probably connected, will influence the upstream conditions of the Atlantic water eventually entering the Arctic Ocean.

\section{Variability in the Eurasian Basin and interactions with shelf outflows}

The largest and most intense transformations of the Atlantic inflow occur in the Nansen Basin and on the shelves of the adjacent Barents and Kara seas. In this area the heat of the Atlantic water has the largest possibility to become mixed into the surface layer and reach the sea ice and the atmosphere. The SPACE (Synoptic Pan-Arctic Climate and Environment Study) cruise with R/V Polarstern in 2007 extended over much of this area, comprising 4 sections reaching from the shelf into the deep basin (Fig. 2a). The sections provide enough spatial resolution to determine the changes in the water mass characteristics along and across the Nansen Basin and to form the basis for a study of the transformations and changes occurring in the basin - in particular, changes in the shelf-basin interactions.

Furthermore, the SPACE sections approximately follow previous sections worked from the shelf into the deep Eurasian Basin and thus provide a temporal dimension of the changes over the last 10-15 yr (Fig. 2b). The two main SPACE sections extended over two-thirds of the Arctic Ocean, reaching from the Eurasian shelf to the Alpha Ridge crossing not only the Nansen Basin but also the Amundsen and Makarov basins as well as the Gakkel and Lomonosov ridges (Fig. 2a). Of the four sections extending from the shelf into the Nansen Basin, the first ran along $33^{\circ} \mathrm{E}$, east of Svalbard, and on the second section the ship returned from the basin along $50^{\circ} \mathrm{E}$ towards Franz Josef Land. The third, main, section was taken from the eastern Kara Sea along $90^{\circ} \mathrm{E}$ across the Nansen and Amundsen basins into the Makarov Basin, and the final section 4 was along the Gakkel Ridge reaching the Laptev Sea at $126^{\circ} \mathrm{E}$. An examination of the shelf-basin exchanges thus naturally starts with section 1 .

The section along $33^{\circ} \mathrm{E}$ extended farthest onto the shelf, and it almost captured the Barents Sea inflow branch close to its entrance at the Barents Sea Opening. The most significant features are seen in the upper $400 \mathrm{~m}$ (Fig. 3). On the northern Barents Sea shelf, the cold remnant of the winter mixed layer dominates between $50 \mathrm{~m}$ and $100 \mathrm{~m}$. It is almost as cold but slightly more saline and denser than the winter mixed layer in the Nansen Basin farther north. The two distinct winter mixed layers are derived from the interactions between sea ice and the two Atlantic inflows. Ice melts on top of the warmer Atlantic water, and the resulting less saline surface waters are homogenised by cooling and later by ice formation in winter (Rudels et al., 1996, 2004). The higher salinity in the Barents Sea winter mixed layer has been suggested due to the fact that the Atlantic water initially encountering sea ice is colder in the Barents Sea than in the Nansen Basin north of Svalbard, and then a smaller fraction of the heat loss goes to ice melt (Rudels et al., 2004).

No connection is seen between the two low salinity upper layers at the shelf break in the northern Barents Sea, where they are separated by warmer and more saline water associated with upwelling of the Atlantic core at the continental slope. However, at section 3 at $90^{\circ} \mathrm{E}$ in the Kara Sea east of the St. Anna Trough, the two mixed layers are observed flowing side by side (see $\theta S$ diagram in Fig. 4). This suggests that transformations of the upper part of the Barents Sea inflow branch occur also farther east in the Barents Sea 

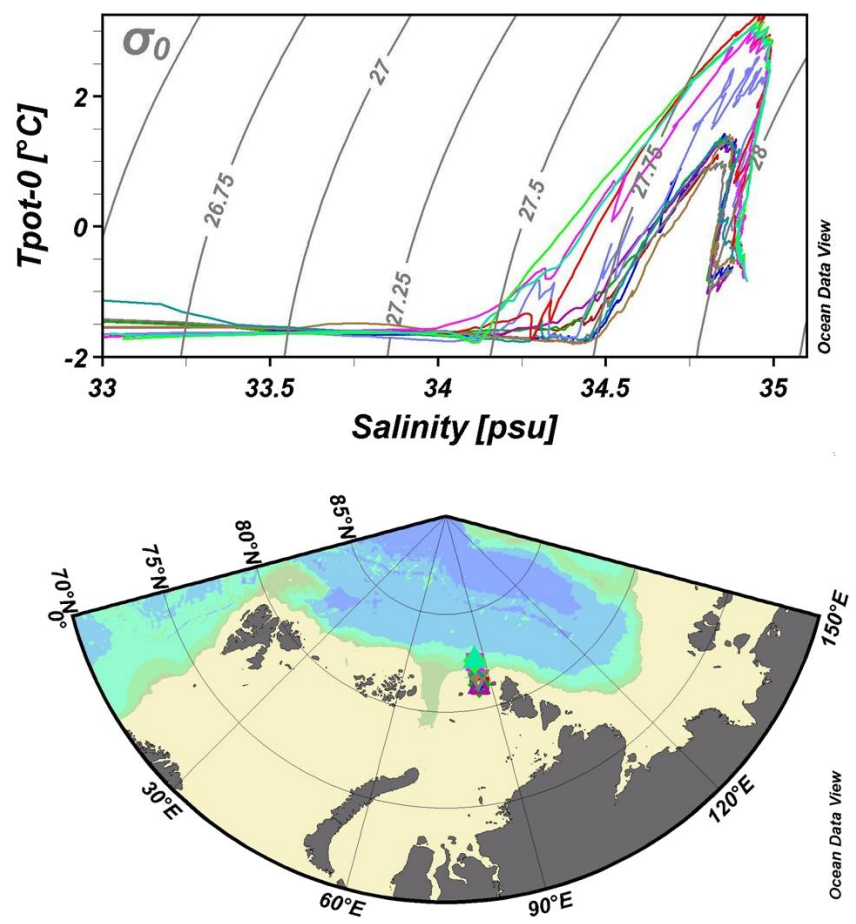

Fig. 4 . $\theta S$ curves from the shelf and slope in the eastern Kara Sea showing the colder, less saline Barents Sea branch on the shelf and the warmer, more saline Fram Strait branch on the slope. The winter mixed layers are located above the thermocline, and here the Barents Sea branch is more saline than the Fram Strait branch.

and in the Kara Sea, and that this part of the branch primarily enters the Nansen Basin via the Kara Sea. Because the Barents Sea branch winter mixed layer is denser than that found in the Nansen Basin, it interacts with, and cools, the thermocline and the upper part of the Atlantic core of the Fram Strait branch as the two branches meet and mix north of the Kara Sea (Fig. 4).

The Atlantic water approaches the sea surface at, or close to, the shelf break north of the Barents Sea, which suggests that this region might be one where a significant heat loss from the Atlantic water to the mixed layer, to sea ice and the atmosphere occurs. This is corroborated by the fact that no upper temperature minimum is found between the surface water and the Atlantic core. This upper minimum is normally a remnant of the local winter convection, and its existence almost everywhere in the Arctic Ocean indicates that the vertical heat transfer in summer is small (Fig. 5). In winter the homogenisation of the upper layer reaches the thermocline in the Nansen Basin but not elsewhere in the Arctic Ocean, and it is possible that upward vertical heat flux occurs in winter in the Nansen Basin. The absence of an upper temperature minimum at the shelf break shows that heat from the Atlantic water reaches the seasonally heated surface layer in summer, and this heat flux should be larger in winter when the stability is weaker. Farther to the east the Barents Sea inflow branch
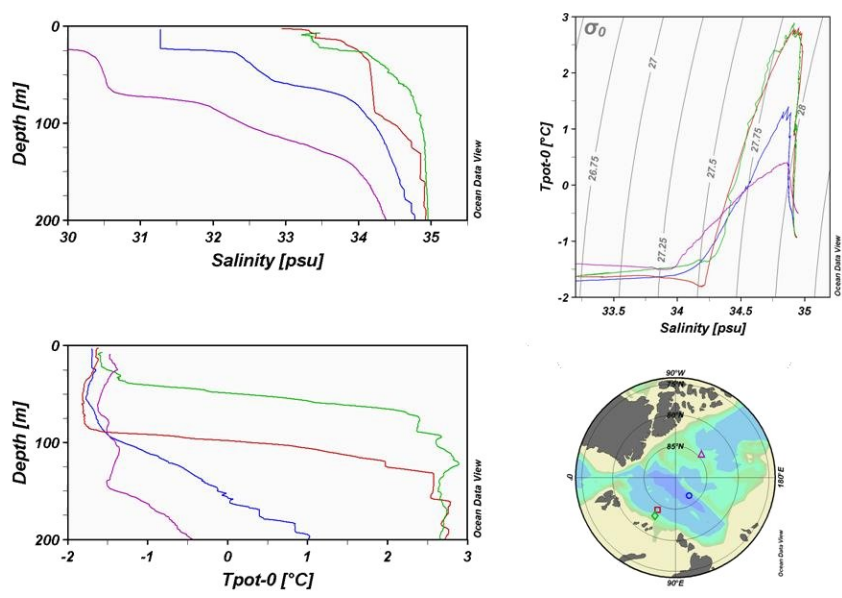

Fig. 5 . Profiles of salinity and potential temperature and $\theta S$ curves from the upper layers in different parts of the Arctic Ocean showing the upper temperature minima created by winter convection. Only at the Eurasian continental slope (green station) is the minimum absent, indicating that warmer water is entrained from below into the mixed layer in summer.

deflects the Fram Strait branch from the slope, and the vertical heat flux at the shelf break becomes smaller and likely less important.

At the southern end of the section, the Atlantic water over the Central Bank in the Barents Sea displays high salinity and density and fairly high $\left(>0^{\circ} \mathrm{C}\right)$ temperature. The bottom density over the bank is as high as or higher than that of the Arctic Ocean deep waters. Whether this high density would survive an advection towards either the Arctic Ocean via the St. Anna Trough or back to the Norwegian Sea in the Bear Island Channel, allowing for a ventilation of the deeper layers in the basins, is another matter. What is significant is that in the 1980s highest densities over the Central Bank were associated with ice formation, and the temperature at the bank was close to the freezing point. However, in years with no ice and warmer, more saline water over the bank, the water column exhibited lower densities, also in comparison with 2007 (Quadfasel et al., 1992). This could indicate that the formation of dense water in the Barents Sea is changing from freezing and brine rejection to just cooling the already saline inflowing Atlantic water. This may be important for the deep water ventilation in the Arctic Ocean.

In the northern, deep part of the section there were differences between the intermediate waters close to the continental slope and those farther to the north (Fig. 6). A sharp decrease in salinity and in temperature of the Atlantic core was observed between the boundary current and the northern part of the Nansen Basin, and large and regular intrusions were found at the northern stations. At the slope a weak salinity minimum is seen at $1500 \mathrm{~m}$ indicating the presence of Arctic Intermediate Water (AIW) or Nordic sea deep water (NSD) from the Greenland Sea. This minimum is not found at the 

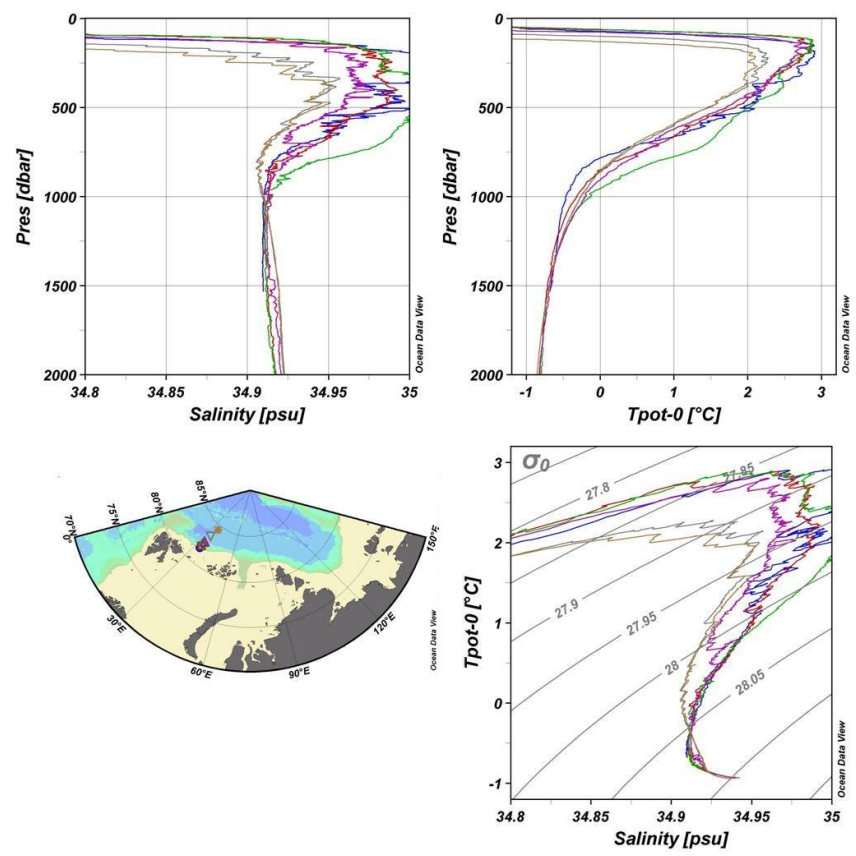

Fig. 6 . Profiles of salinity and potential temperature, and $\theta S$ curves from the deep stations on the first SPACE section. Notice the colder, less saline Atlantic water and the salinity minimum at $900 \mathrm{~m}$ at the northern stations and the deep $(1500 \mathrm{~m})$, weak salinity minimum closer to the slope (better seen in the $\theta S$ diagram).

northern stations. Instead a salinity minimum is observed around $900 \mathrm{~m}$. The most probable source for this minimum is the Barents Sea inflow branch (Fig. 6). This suggests that the water column in the northern part of the section either partly is derived from the Barents Sea branch or has been in close mixing contact with the St. Anna inflow.

The second section, extending from the Nansen Basin towards Franz Josef Land, showed a similar warm Atlantic core as section 1, but the section evidently did not extend far enough into the basin to observe the temperature and the salinity decrease seen in section 1 . However, close to the slope the profiles became more rugged and irregular and cold intrusions appeared (Fig. 7). This resulted in a lowering of the salinity and temperature of the Atlantic core. The origin of the cold intrusions was the result of outflows of cold, less saline water from the Barents Sea, which would mainly occur in the Victoria Channel between Victoria Island and Franz Josef Land. Cold, low salinity water was observed below the Atlantic layer at the slope north of Franz Josef Land in 1980 (Rudels, 1986) and in 1993 (Schauer et al., 1997), and these observations were taken as evidence that dense outflows from the Victoria Channel were taking place (Rudels and Friedrich, 2000). The earlier observations showed one strong cold and fresh intrusion, and not the vertically more widespread interleaving observed in 2007 (Fig. 7). In 2007 colder and denser water also was present at the upper part of the slope, which eventually also could penetrate to larger
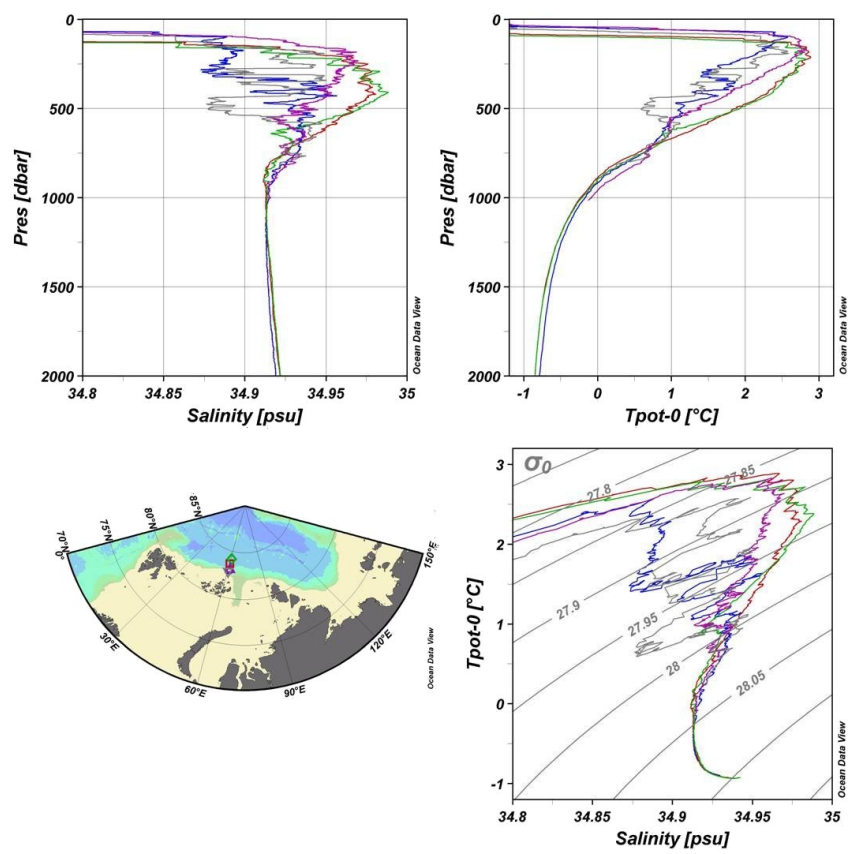

Fig. 7 . Profiles of salinity and potential temperature and $\theta S$ curves from the second SPACE section north of Franz Josef Land showing the intrusions of colder and less saline water from the Barents Sea in the water column at the slope.

depth (Fig. 8, blue station). The difference between the years could be due to ice formation and brine rejection in the polynya area around Franz Josef Land (Martin and Cavalieri, 1989). However, the ice conditions around Franz Josef Land in 2007 did not appear to be significantly different from other years, so this has to remain a speculation. Some stations were also obtained in the western St. Anna Trough, unfortunately not capturing the main Barents Sea outflow but showing Fram Strait branch water entering the St. Anna Trough from the north and mixing with colder, less saline shelf water (Fig. 8).

The third section started in the eastern Kara Sea east of the St. Anna Trough, the major passage for the dense Barents Sea branch water entering the Arctic Ocean. The difference between the winter mixed layer in the Nansen Basin and in the Barents Sea branch has been discussed above and is shown in Fig. 3. The denser waters of the Barents Sea branch, which on the section are located above the $400 \mathrm{~m}$ isobath on the upper part of the slope, are dense enough to mix into the core of the Atlantic layer and to penetrate into the intermediate layers below. The densest part of the Barents Sea branch inflow appears to form a separate stream and sinks directly from the St. Anna Trough into the intermediate layer creating a deep, less saline intrusion in the boundary current (Fig. 8). On the shelf three distinct dense contributions from the Barents Sea branch can be identified: a warm Atlantic core with temperatures slightly above $1{ }^{\circ} \mathrm{C}$ and salinity around 34.88 ; below the warm core a temperature minimum with $\theta \sim-1{ }^{\circ} \mathrm{C}$ and 

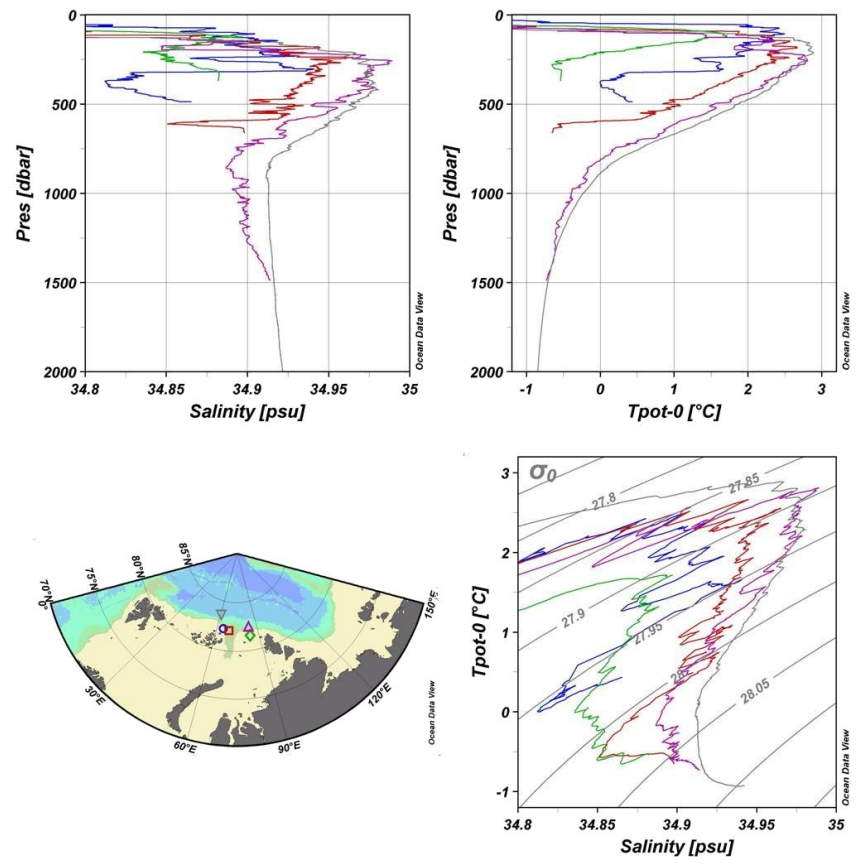

Fig. 8 . Profiles of salinity and potential temperature and $\theta S$ curves from the Nansen Basin (grey station) and from the shelf (blue station) north of Franz Josef Land and from St. Anna Trough (red station) showing the warmer Fram Strait branch Atlantic water and the denser water on the shelf and the Fram Strait branch water entering the trough from the north. The green and magenta stations on the Kara Sea shelf and slope show the Barents Sea branch remaining on the shelf, but the denser part of the Barents Sea inflow is seen as a low salinity layer at the slope between $750 \mathrm{~m}$ and $1500 \mathrm{~m}$ (magenta station).

salinity just above 34.8 are present; and at the bottom a dense part with temperature around $-0.5^{\circ} \mathrm{C}$ and salinity $\sim 34.88$ is found. These characteristics are close to those observed in St. Anna Trough in 1996 (Schauer et al., 2002a), where the cold intermediate part was attached to the eastern flank of the trough, while the densest, slightly warmer water was found in the deepest part of the trough. A simple interpretation would then be that the densest part is derived from the Barents Sea, probably from the shallow area west of Novaya Zemlya, while the colder contribution is formed on the northern banks of the Kara Sea east of the St. Anna Trough from where it drains to join the main Barents Sea outflow. The temperature maximum would be the remnant of the Atlantic water core entering at the Barents Sea opening (Fig. 9). One caveat exists in this interpretation. The Atlantic water from Fram Strait that moves up the St. Anna Trough could jump stream and join the Barents Sea branch higher on the slope and shelf break and thus increase the temperature of the Atlantic water in the Barents Sea branch. What argues against this is that the mixed layer in the Barents Sea branch is more saline than in the Fram Strait branch, which would indicate
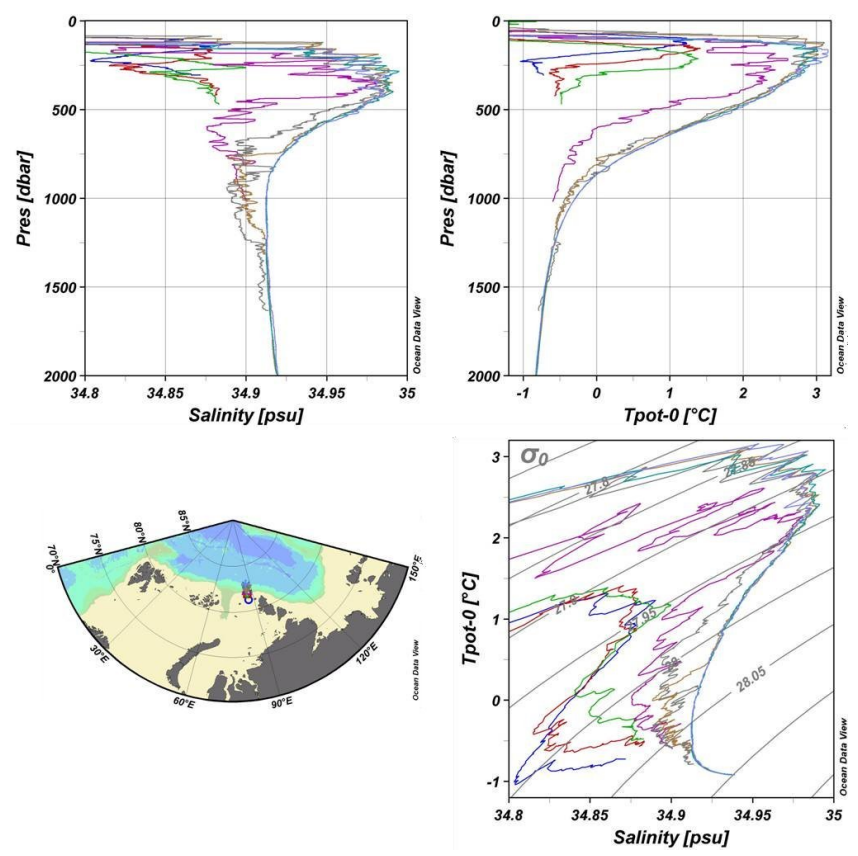

Fig. 9 . Profiles of salinity and potential temperature and $\theta S$ curves from the shelf and slope in the eastern Kara Sea. The three dense contributions from the Barents Sea are seen as a temperature maximum, a salinity and a temperature minimum, and a cold, more saline bottom water. The magenta station shows strong isopycnal mixing between the two branches. On the slope Barents Sea branch water that has entered the deep basin directly from the St. Anna Trough is seen as a low salinity layer (grey and yellow stations). The intrusions in the Fram Strait branch are found at the temperature maximum but above the salinity maximum.

that ice has been melting on top of colder water, which is the case in the Barents Sea (see above and Rudels et al., 2004).

At section 3 the stream located at the shelf break has not yet begun to mix with the Fram Strait branch, and the front between the two branches is distinct and narrow. Only one station was showing large intrusions, especially in the warm core. The temperature and the salinity of the main part of the Fram Strait branch Atlantic core are similar to those found on sections 1 and 2, implying that no significant cooling has occurred between Svalbard and the eastern Kara Sea. Most of the intrusions and interleaving observed in the Fram Strait branch were here found above and at the temperature maximum, but above the salinity maximum (Fig. 9).

At section 4, along the Gakkel Ridge onto the Laptev Sea this has all changed. The temperatures and salinities of the temperature and salinity maxima of the two branches have become more equal. The range is still fairly wide with a temperature difference of $1^{\circ} \mathrm{C}$ and a salinity difference of 0.05 compared to $2^{\circ} \mathrm{C}$ and 0.1 , respectively, at Sect. 3 (Fig. 10). The Atlantic core displays distinct intrusions located primarily at and below the temperature maximum but above the salinity maximum, and the salinity minimum from the 

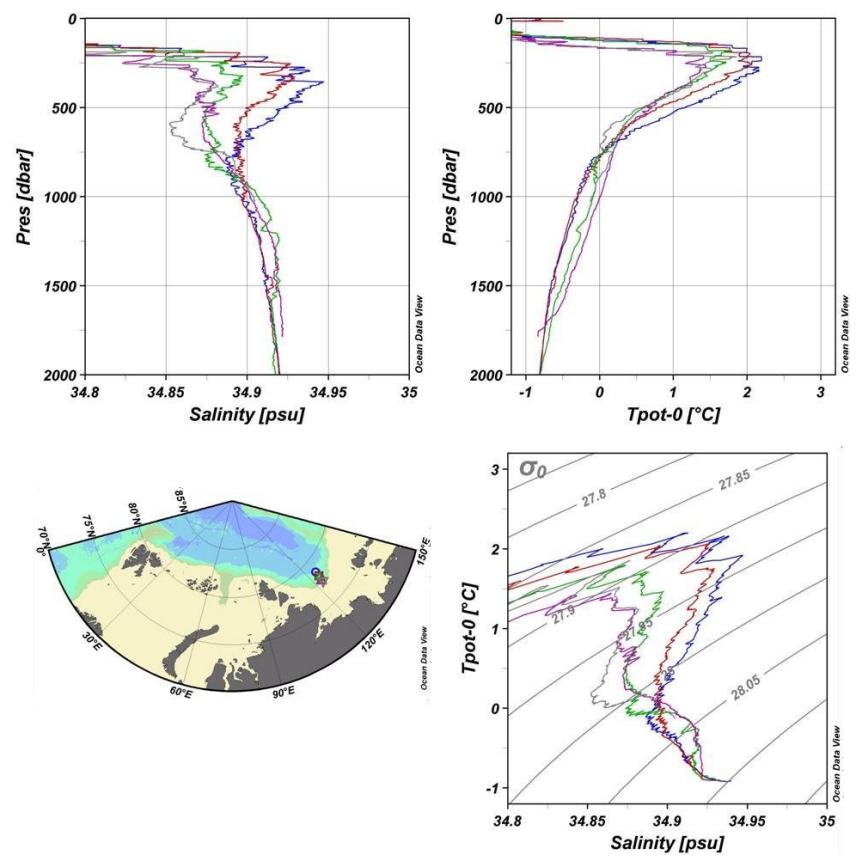

Fig. 10 . Profiles of salinity and potential temperature, and $\theta S$ curves from the Laptev Sea slope. No smooth temperature and salinity profiles are seen in the Fram Strait branch Atlantic core, and the presence of intrusive layers indicates mixing between the branches. The Atlantic water is still warmer and more saline over the deeper part of the slope (red and blue stations) than closer to the shelf but has become considerably colder and less saline compared with section 3 (Fig. 9).

Barents Sea branch has spread from the slope into the Fram Strait branch.

The temperature reduction observed in the Fram Strait branch Atlantic core between the Kara Sea and the Laptev Sea is the largest one occurring along the Eurasian slope.

This is more clearly seen by comparing the temperature and salinity sections taken across the slope at the different crossings (Fig. 11). The warm and saline Fram Strait branch is affected somewhat by mixing with Barents Sea branch water north of Franz Josef Land. North of the Kara Sea it is forced off the slope by the Barents Sea inflow branch east of the St. Anna Trough, but it still retains its high temperature. North of the Laptev Sea, really large changes can be seen in the characteristics of the Fram Strait branch. The Atlantic water core has become colder by $1^{\circ} \mathrm{C}$, its salinity reduced by 0.05 , and the core displaced farther away from the slope.

One obvious and possible cause for the reduction in temperature is isopycnal mixing with the colder Barents Sea branch, and the intrusions found in the Atlantic layer indicate strong lateral mixing between the branches. A frontal zone still remains at the slope between the Fram Strait branch and the Barents Sea branch. On the basin side of the Fram Strait branch, continuing section 4 along the Gakkel Ridge, the temperature and salinity of the Atlantic core again de- crease and approach the values found for the Barents Sea branch at the slope (Fig. 12). Interleaving is present, and the maxima and minima of the different stations appear to line up in the $\theta S$ curves and also in the profiles.

A similar structure is found at section 3 on the basin side of the warm Atlantic core (Fig. 13). Here the frontal structure is more distinct. Just beyond the warm Fram Strait branch, the temperature and salinity decrease by more than $0.6^{\circ} \mathrm{C}$ and 0.04 , respectively, to values close to the maxima observed on the Laptev Sea section. Farther into the basin another front is present, and the temperature and salinity drop to just above $1{ }^{\circ} \mathrm{C}$ and below 34.9, close to the values of the Barents Sea branch at its temperature maximum, and similar to what was observed at the Laptev Sea slope. These temperature and salinity characteristics then hold for the Atlantic layer in the entire Amundsen Basin up to the Lomonosov Ridge, where the temperature again increases slightly (see e.g. Fig. 16b below).

Interleaving structures are present at the basin side of the first front as well as an intermediate salinity minimum, less distinct over the Gakkel Ridge and in the Amundsen Basin in spite of lower salinity because of the lower temperature and salinity in the Atlantic layer. The lower salinity and the interleaving structures on the basin side of the Fram Strait branch indicate water with a significant, or even dominant, Barents Sea branch component. The temperature and salinity in the Atlantic layer are close to those of the Atlantic layer of the Barents Sea branch at the Kara Sea slope, but the salinity minimum is significantly reduced (Figs. 9 and 13). This is likely due to the higher density of the less saline water, which north of the Kara Sea was located high at the slope and had to descend, mixing with ambient Fram Strait branch water, before it reached its neutral density level (Fig. 11).

This implies that the Barents Sea branch in general supplies most of the Atlantic water masses beyond the Laptev Sea and that the Fram Strait branch becomes markedly eroded by lateral mixing with Barents Sea branch water, initially in the boundary current along the Eurasian slope north of Severnaya Zemlya, but also by mixing on the basin side of boundary current. Here interleaving and large intrusions are seen in the Atlantic layer between the temperature maximum and the salinity maximum, whereas interleaving and intrusions with smaller vertical extent are observed below the salinity maximum and in the underlying salinity minimum. The much lower temperature and especially the much lower salinity observed in the Atlantic core in the boundary current and in the basins suggest that the transport of the Fram Strait branch water in the boundary current would then be all but extinguished in the boundary current north of the Laptev Sea. Beyond the Gakkel Ridge, in the Amundsen Basin and in the Amerasian Basin beyond the Lomonosov Ridge, the Atlantic inflow, except the Fram Strait contribution to the lower halocline, would mainly be derived from the inflow over the Barents Sea (Fig. 14). 

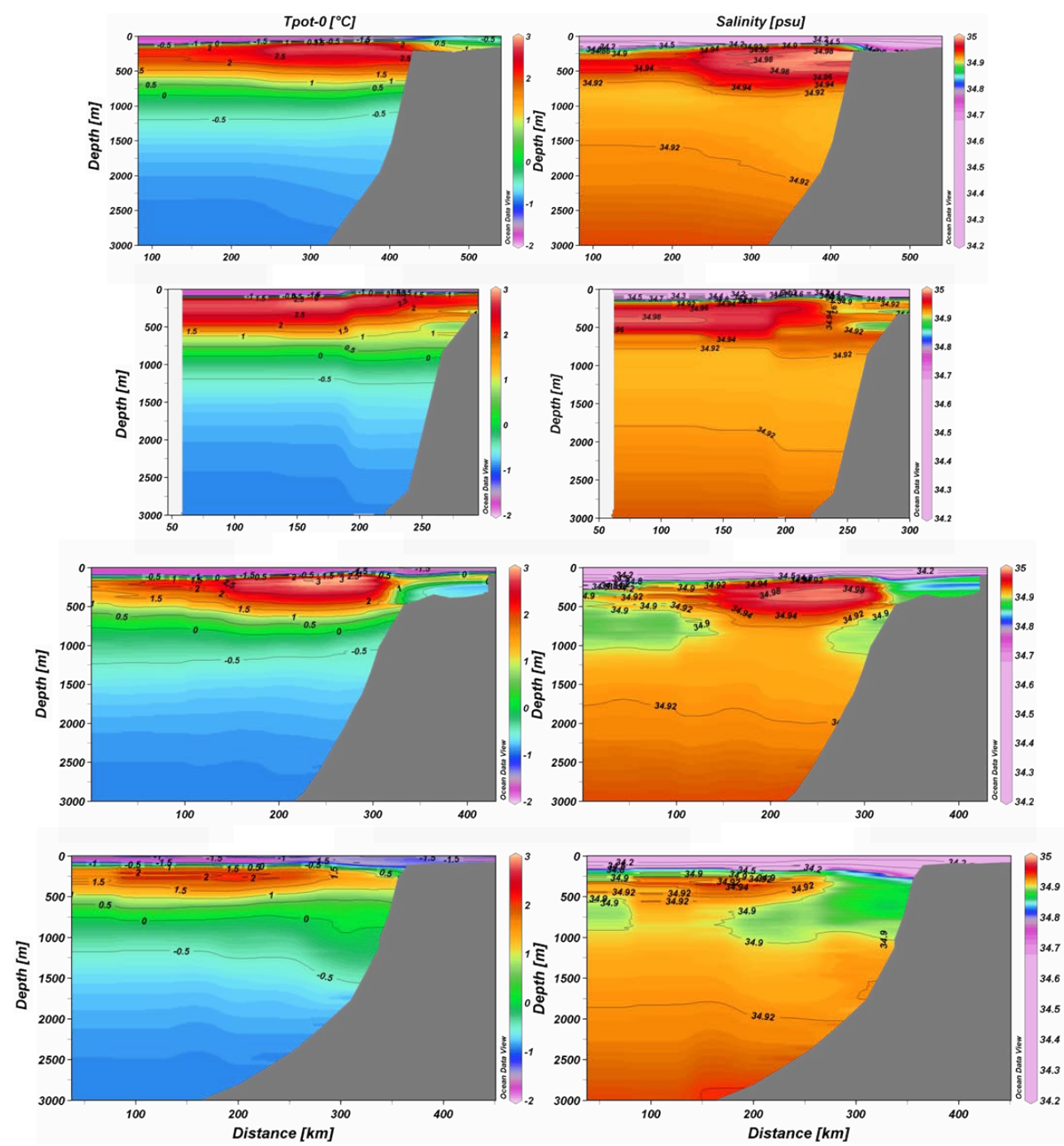

Fig. 11 . Potential temperature and salinity sections from the shelf into the deep Nansen Basin: upper panel - western Barents Sea; upper centre panel - Franz Josef Land; lower centre panel - eastern Kara Sea; lower panel - Laptev Sea.

That the influence of the Atlantic inflow through Fram Strait would be limited to the Nansen Basin is surprising, considering that the estimate of Atlantic water entering the Arctic Ocean through Fram Strait and continuing eastward along the Eurasian slope, 2-3 Sv (Schauer et al., 2004, 2008; Beszczynska-Möller et al., 2012), is almost twice that entering the Barents Sea Opening (Skagseth et al., 2008). A more detailed study of the heat and freshwater content in the Atlantic layer in the different basins also reveals the larger heat and the smaller freshwater contents in the Nansen Basin compared with the rest of the Arctic Ocean (Korhonen et al., 2012). If most of the Fram Strait branch water hardly enters the Amundsen Basin, not to mention the Amerasian Basin, the situation observed in the Amundsen Basin and over the Gakkel Ridge in 2007 can be understood. Such close recirculation would explain the high temperatures of some of the Arctic Atlantic water returning towards Fram Strait. It would also explain the lower salinity and the strong interleaving found on the basin side of the boundary current on section 1 and section 3. The lower salinity and the intrusions would be remnants from the initial mixing with the Barents Sea branch water that began at the slope north of Severnaya Zemlya. This suggests a flow pattern for the Atlantic and intermediate layers similar to that shown in Fig. 15.

This situation, observed in 2007, cannot always be present. The inflow of warm Atlantic water into the Makarov Basin observed in 1993 (Carmack et al., 1995) and the high temperatures found on the Arctic Ocean section in 1994 (Carmack et al., 1997; Swift et al., 1997) and on the Polarstern section in 1996 (Schauer et al., 2002b) at the Lomonosov Ridge indicate that Fram Strait branch water occasionally passes beyond the Gakkel Ridge, not just by mixing and heating the Barents Sea branch but also as a distinct contribution, retaining some of its high temperature and salinity characteristics. It would then recirculate along the Lomonosov Ridge and in the Amundsen Basin and also cross the Lomonosov Ridge into the Amerasian Basin. The reports from the NABOS moorings north of the Laptev Sea show that the temperature 

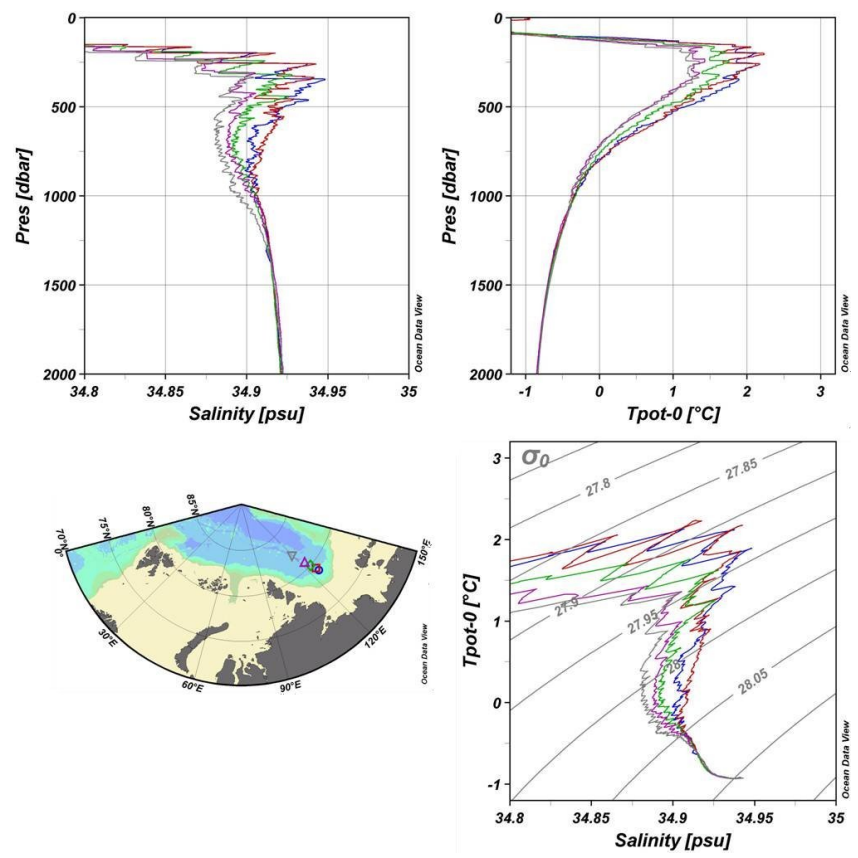

Fig. 12 . Profiles of salinity and potential temperature and $\theta S$ curves from SPACE section 4 along the Gakkel Ridge showing the regular interleaving layers and the gradual reduction in temperature and salinity from the slope to the basin.

of the Atlantic layer increased suddenly in the early part of 2000s (Dmitrenko et al., 2005; Polyakov et al., 2005). Whether this was mainly due to warmer Fram Strait water entering the Arctic Ocean, or if different conditions north of the Laptev Sea can either allow the Fram Strait branch water to pass farther to the east or confine it to the Nansen Basin, is to date an unsolved question. Should the recent observed warming and changes in the Amerasian Basin be due to an increased inflow of warm Fram Strait branch water passing eastward at Severnaya Zemlya, the Laptev Sea area would be a critical choke point for the circulation of Atlantic water in the Arctic Ocean. Another possibility is that the changes downstream of the Laptev Sea mainly reflect variability in the Barents Sea branch, bringing either warmer or colder Atlantic core water over the Barents Sea into the Arctic Ocean.

The "Atlantic" part is here interpreted as a part of the Atlantic water from the Norwegian Sea that has survived the heat loss in the Barents Sea and retained a comparably high temperature. Another possibility or modification also exists; warm Fram Strait branch water that enters the St. Anna Trough from the north could become mixed into the Barents Sea branch in the trough and "jump stream" and join the Barents Sea branch on the shelf, contributing the comparably high Atlantic water temperatures observed there (see above and Fig. 4).
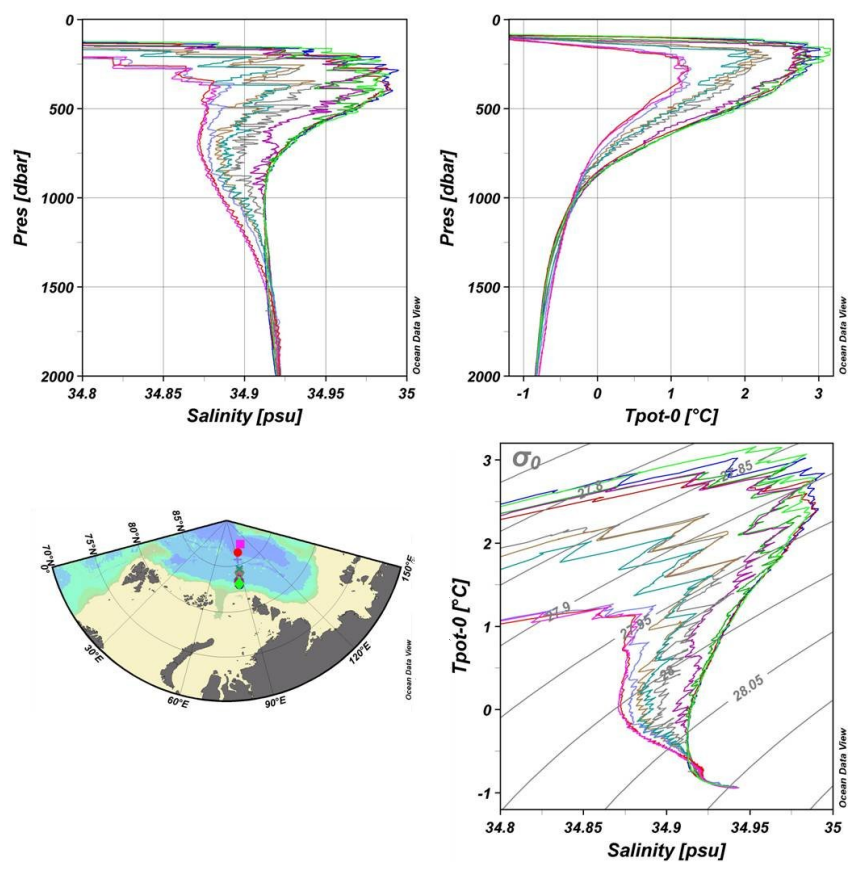

Fig. 13. Profiles of salinity and potential temperature, and $\theta S$ curves from the SPACE section 3 from the slope into the Amundsen Basin. The temperature and salinity decrease towards the Amundsen Basin and two fronts are seen, both located in the Nansen Basin, where also the strongest interleaving is observed. The interleaving layers are here mostly located below the temperature maximum and at and below the salinity maximum. This is different from the situation at the slope (Fig. 9).

\section{Time variability in the Eurasian Basin}

A comparison of temperature and salinity sections taken in the Eurasian Basin from the Gakkel Ridge across the Amundsen Basin and over the Lomonosov Ridge into the Makarov Basin in 1991, 1996, 2001, 2005 and 2007 shows the time variability of the temperature of the Atlantic layer. We assume that the area covered, except the Makarov Basin, represents a flow towards Fram Strait (Fig. 16). The situation in 1991 shows that the Atlantic layer over the Gakkel Ridge is warmer than in the Amundsen Basin and at the Lomonosov Ridge. The temperature at the Lomonosov Ridge is higher than in the Amundsen Basin, but both temperatures are close to the temperature maximum of the Barents Sea branch. The temperature in the Makarov Basin is considerably lower. In 1996 the Atlantic water temperature over the Gakkel Ridge is slightly lower, while the temperature over the Lomonosov Ridge has become significantly higher and is even higher than at the Gakkel Ridge. The Amundsen Basin has also become markedly warmer and the Makarov Basin slightly warmer. The changes in the Amundsen Basin and at the Lomonosov Ridge can be understood, if the inflow of warmer Atlantic water observed in 1990 (Quadfasel et al., 1991), which by then would have penetrated beyond the 

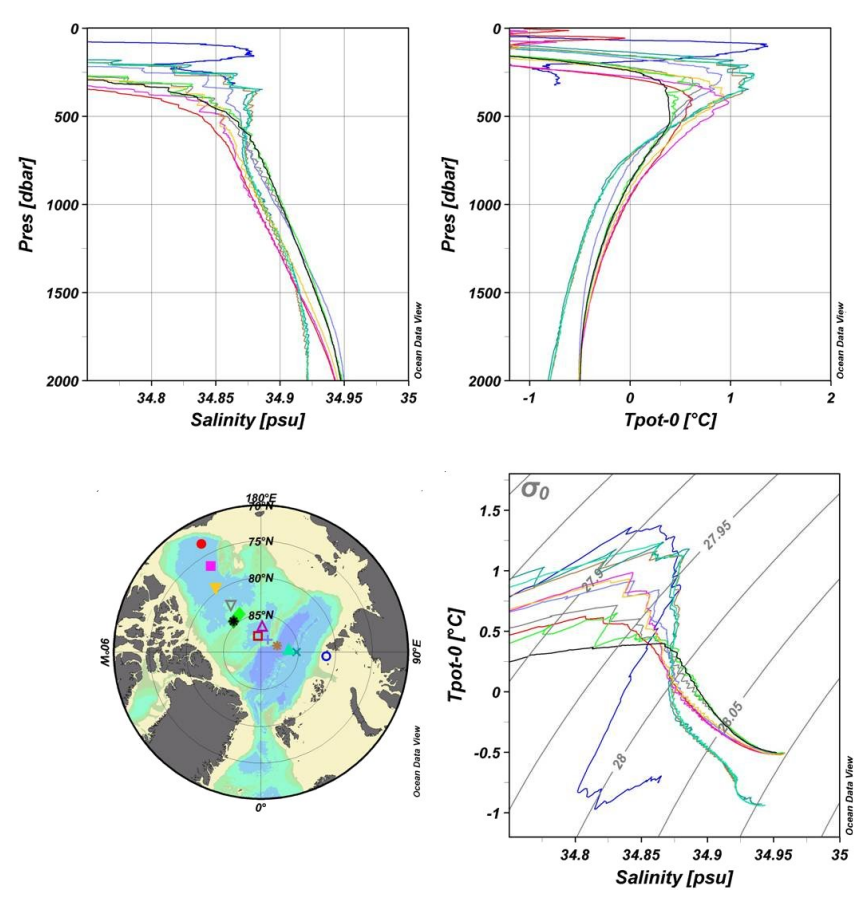

Fig. 14 . Profiles of salinity and potential temperature and $\theta S$ curves showing the properties of the Barents Sea branch and the characteristics of the water column in the Amundsen Basin, Makarov Basin and Canada Basin and over the Lomonosov Ridge and over the Mendeleev and Alpha ridges. The Barents Sea branch is warm enough to supply the temperature maximum in most of the Arctic Ocean basins.

Laptev Sea choke point, was returning towards Fram Strait, more rapidly along the Lomonosov Ridge than in the central Amundsen Basin.

In 2001 the Gakkel Ridge area was again the warmest and this also held for 2005 and 2007. This returning branch will contain a large fraction of Fram Strait branch Atlantic water, and the variations between the years could reflect, with a time lag, the temperature variations of the Fram Strait inflow returning over the Gakkel Ridge. The temperature over the Lomonosov Ridge decreased between 1996 and 2001, while the temperature in the Amundsen Basin increased slightly. Both the Amundsen Basin and the Lomonosov Ridge temperatures dropped drastically in 2005. This only holds for half of the Amundsen Basin though. The stations closer to the Gakkel Ridge showed higher temperatures, gradually approaching those at the Gakkel Ridge. In the Makarov Basin the temperature had increased and was similar, or even higher than, at the Amundsen Basin side of the Lomonosov Ridge. This suggests that the warm Atlantic water entering the Makarov Basin in the 1990s (Carmack et al., 1995) now had circulated around the basin and was moving along the Lomonosov Ridge towards Siberia. A similar interpretation was made earlier by Kikuchi et al. (2005). In the Amundsen Basin and over the Lomonosov Ridge, the lower tempera-

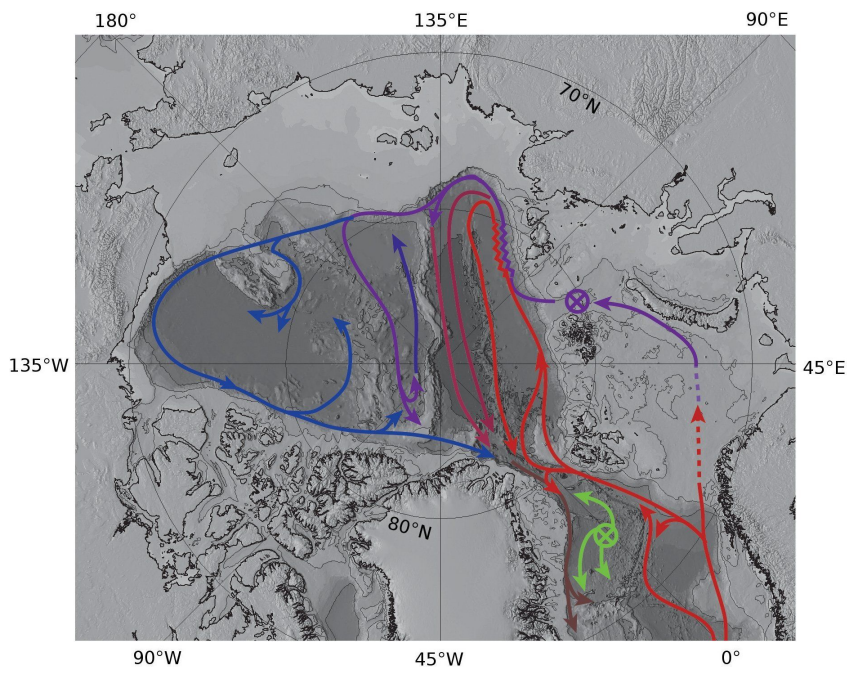

Fig. 15 . Circulation schematics for the Atlantic and intermediate waters showing the two inflow branches and their suggested distribution in the Arctic Ocean. Red colour indicates warm Atlantic water and the Fram Strait branch, and magenta shows the cooled, less saline Barents Sea branch. After the confluence and mixing of the branches north of Severnaya Zemlya, the main part of the Fram Strait branch water returns to Fram Strait in the Nansen Basin (red stream), while the Barents Sea branch dominates in the other basins. The colour scale indicates the amount of Fram Strait branch water present, more in the Amundsen Basin and at the Lomonosov Ridge than in the Makarov Basin. Shelf processes in the Canada Basin change the intermediate water properties, indicated by blue streams and arrows, and part of this water enters the Makarov Basin from the North American slope and flows along the Lomonosov Ridge towards Siberia. The loops from the different basins exit through and merge in Fram Strait. The green streams indicate Arctic Intermediate Water created by convection in the Greenland Sea and partly advected into the Arctic Ocean through Fram Strait. (Figure redrawn from Rudels et al., 2012 and adapted from Rudels et al., 1994.)

tures imply that the warm Fram Strait branch water has been replaced by mostly Barents Sea branch water, supplying the Eurasian Basin beyond the Laptev Sea. This also correlates with the lower temperatures observed at the NABOS stations north of the Laptev Sea in the early 2000s (Dmitrenko et al., 2005). In 2007 the Makarov Basin temperature was somewhat reduced while the temperature at the Lomonosov Ridge was slightly higher than in 2005 , indicating possible presence of Fram Strait branch water or a warmer Barents Sea branch inflow at the Lomonosov Ridge. Over the period 1991 to 2007, there also appears to be a slight decrease in salinity of the Atlantic and intermediate layers between the Gakkel Ridge and the Makarov Basin. This all implies a rather rapid advection of the Atlantic water also in the interior of the basins and that the waters in the Amundsen Basin and at the Eurasian side of the Lomonosov Ridge are exchanged by advection from the Laptev Sea. On the Makarov Basin side of 

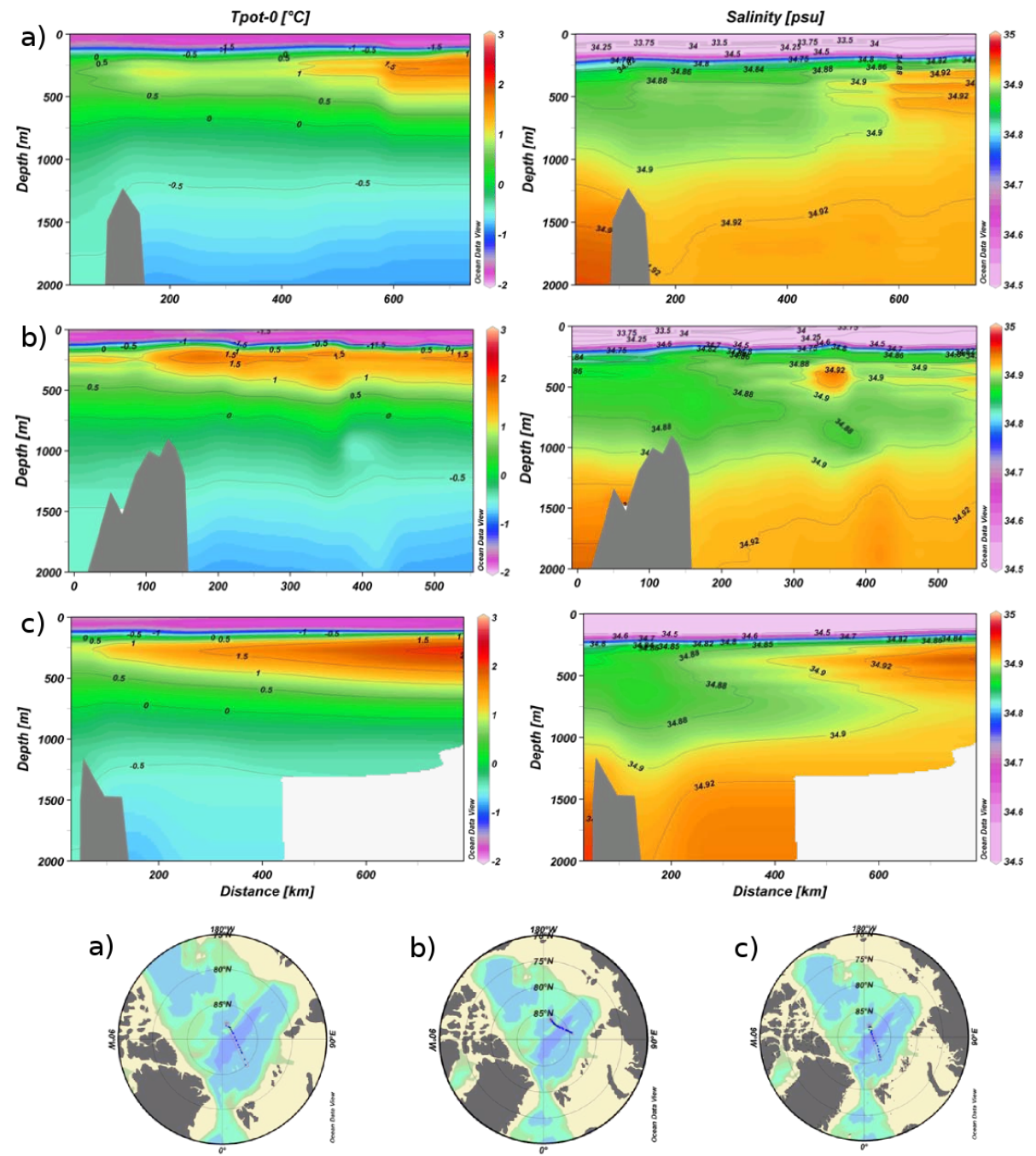

Fig. 16a. Sections of potential temperature and salinity from the Gakkel Ridge (right) across the Amundsen Basin and the Lomonosov Ridge into the Makarov Basin from different years: upper panel and left map - 1991 (Oden); centre panel and centre map - 1996 (Polarstern); lower panel and right map - 2001 (Oden).

the Lomonosov Ridge, the circulation is different, with a flow along the ridge towards Siberia.

It thus indicates that two pulses of warm Atlantic water from Fram Strait have passed through the Eurasian Basin. The first pulse observed in 1990 (Quadfasel et al., 1991) was returning towards Fram Strait in 1996 and had completely left the Eurasian Basin in 2005, while it still was present in the Makarov Basin, moving along the Lomonosov Ridge towards Siberia. The second pulse, first seen in Fram Strait in 1998, was observed north of the Laptev Sea in 2003 (Polyakov et al., 2005; Dmitrenko et al., 2008) and could be detected by the higher temperatures in the Amundsen Basin and over the Lomonosov Ridge in 2007. This suggests a time delay of 2-3 yr between the Laptev Sea slope and the North Pole, which corresponds to an advection velocity of $0.02 \mathrm{~m} \mathrm{~s}^{-1}$.

\section{Thermohaline intrusions}

The almost universal presence of intrusions and interleaving structures in the Arctic Ocean deserves some comments. The intrusions are most frequent in frontal zones, indicating that they are created by the meeting and mixing of different water masses. This was the situation in 2007 north of Franz Josef Land and north of the Kara Sea. North of the Laptev Sea well-established intrusions were observed. This was also the case on the basin side of the Fram Strait branch on the third and the first sections (see Figs. 6, 7, 9, 10, 12, and 13 above). The presence of intrusions on the basin side of the Fram Strait branch has been taken as indication of a flow toward Fram Strait (Rudels et al., 1994). The advective velocities are with great certainty larger than cross frontal velocities of the intrusions caused by double-diffusive convection. Woodgate et al. (2001) determined the advection velocities 

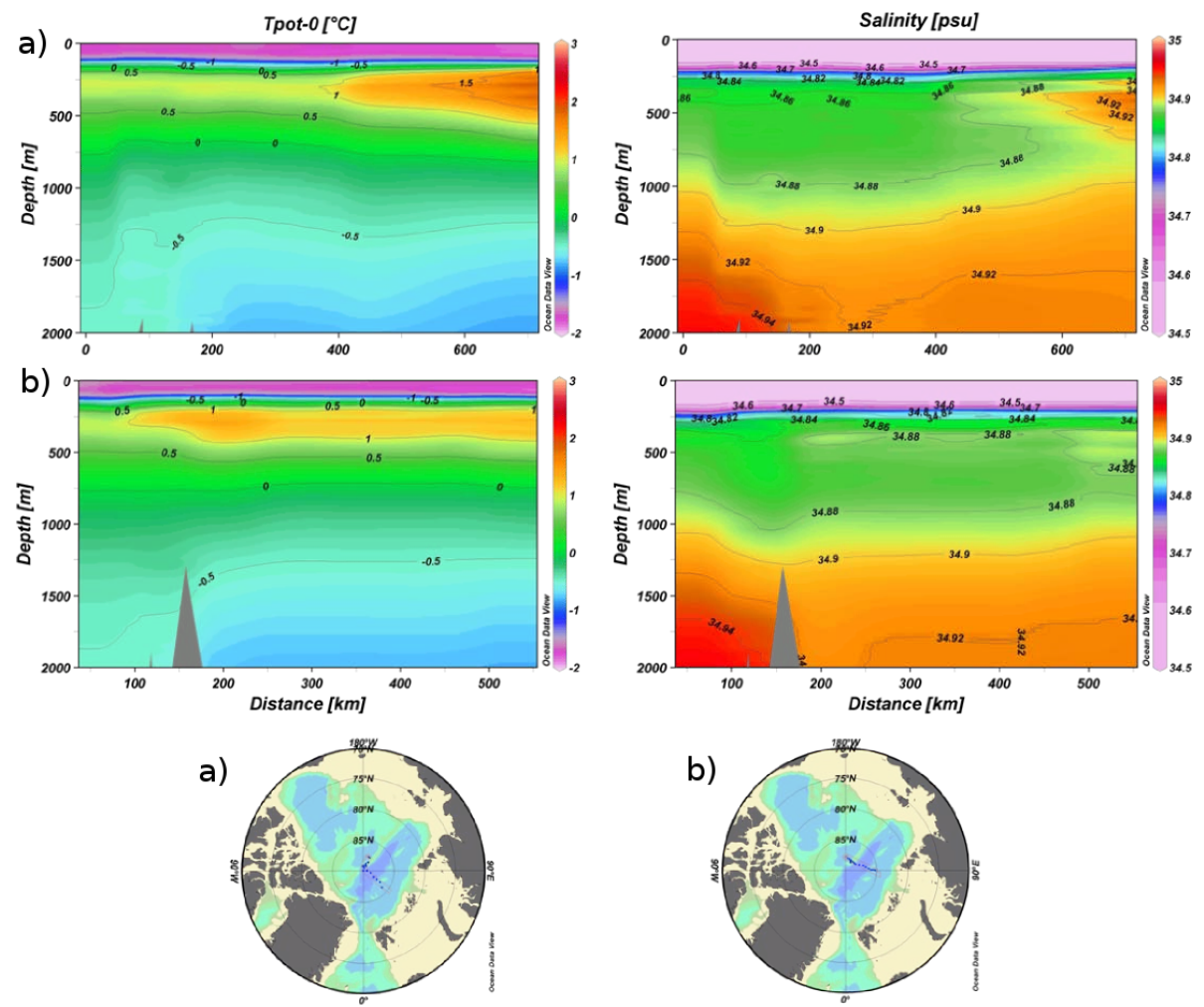

Fig. 16b. Sections of potential temperature and salinity from the Gakkel Ridge (right) across the Amundsen Basin and the Lomonosov Ridge into the Makarov Basin from different years: upper panel and left map - 2005 (Oden); lower panel and right map - 2007 (Polarstern).

in the boundary current north of the Laptev Sea at 0.02 to $0.05 \mathrm{~m} \mathrm{~s}^{-1}$ from direct current measurements, while Walsh and Carmack (2003) estimated the velocities in the interleaving intrusions to be about $0.002 \mathrm{~m} \mathrm{~s}^{-1}$, about one order of magnitude smaller. If intrusions develop in a strong horizontal shear, they would become stretched along the front by the shear, which would obstruct any significant cross frontal flow. The simpler view is that the two water masses move together, and the evolution of the intrusions can be described from a coordinate system following the motion. Since the less saline water on the basin side of the Fram Strait branch is derived from the Barents Sea inflow, the most obvious route would be first eastward along the slope, after which both branches partly leave the slope and flow westward towards Fram Strait.

Whether the intrusions primarily are created during the eastward moving phase, when the gradients are strongest and subsequently advected westward, or if they form in the interior of the basin is not yet known. Much about the formation of Arctic Ocean intrusions is not well understood (for a short summary see Rudels et al., 2009). They are found in all possible background stratifications, also when both heat and salt are stably stratified and linear stability theories do not work. Differential diffusion has been suggested as an important mechanism in these situations (Merryfield, 2002), but the time to establish the intrusions would then be on the or- der of years (Merryfield, 2002; Kuzmina et al., 2011). This appears long considering the interleaving structures in the intermediate depth range encountered along the continental slope and in the eastern Nansen Basin (Figs. 7-9), and also by the occurrence of intrusions almost immediately, when the Makarov Basin deep water passes through the intra-basin in the Lomonosov Ridge into the Amundsen Basin (Björk et al., 2007).

\section{Deep and bottom waters}

The temperature and salinity profiles and the $\theta S$ curves indicate that the deep and bottom waters of the Arctic Ocean are renewed, or at least transformed, within the Arctic Ocean. The strong stratification in the upper part of the deep basins excludes deep convection, and the most likely process is ice formation in lee polynyas over the shallow shelves (Nansen, 1906). Freezing and brine rejection create saline and dense waters that eventually cross the shelf break and descend into the deep Arctic Ocean as entraining boundary plumes. When the plumes reach their neutral density level, they merge with the surrounding water. Depending upon their initial density (salinity), the plumes may supply the halocline, merge with the waters of the boundary current, or bypass the intermediate layers and enter the deep and bottom waters. Because of 

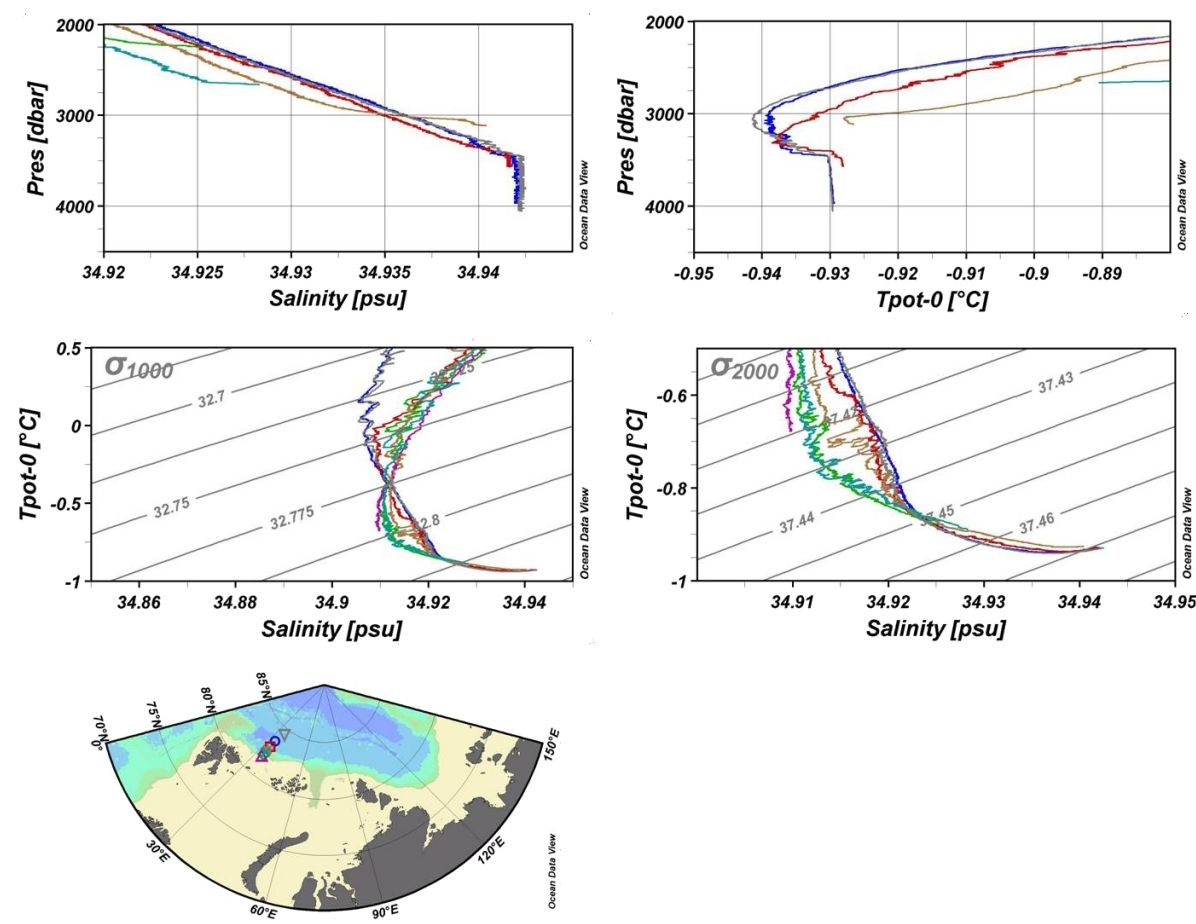

Fig. 17 . Profiles of salinity and potential temperature and $\theta S$ curves showing the characteristics of the deep and bottom water in the Nansen Basin on the SPACE section along $33^{\circ} \mathrm{E}$ and the presence of then deep temperature minimum and the homogenous bottom layer below (profiles) and the less saline deep inflow from the Nordic seas through Fram Strait ( $\theta S$ curves).

the entrainment of ambient water during their descent, the temperature of the plumes increases and their salinity decreases. Below 2000-3000 $\mathrm{m}$ the plumes add both heat and salt to the water column creating a layer of increasing salinity and temperature towards the bottom (Rudels, 1986; Quadfasel et al., 1988). Simple models of entraining plumes, some employing transient tracers, have been used to estimate the ventilation of the deep layers in the Arctic Ocean and to obtain residence times for the deep waters in the different basins (Rudels et al., 1994; Jones et al., 1995; Anderson et al, 1999).

The evolution of the deep water along the Eurasian Basin continental slope can be seen in the deeper layer on the different sections. At the first section a less saline layer at 1500-2000 $\mathrm{m}$ indicates a presence of Arctic Intermediate Water or Nordic sea deep water (Fig. 17). This less saline layer is also observed on the second and third section, but here the salinity has increased somewhat. The deep Barents Sea branch inflow occurs before section 3, and on section 3 it is seen as a reduction of the salinity between 1000 and $1500 \mathrm{~m}$, and the vertical deep part of the $\theta S$ curves of sections 1 and 2 starts to bend towards lower salinity (Fig. 18). First at the Laptev Sea section 4 there are indications of convecting water increasing the salinity in the deeper layer and thus changing the slope of the $\theta S$ curves, making it more perpendicular to the isopycnals (Fig. 19). Observations of high aluminium concentrations in the deep and bottom water also point to the shelves as contributing to the deep waters (Mid- dag et al., 2009). The plumes observed in 2007 were, however, not dense enough to renew the deepest layers, which thus appear to be ventilated under harsher conditions than those prevailing during the last $10-15 \mathrm{yr}$.

Two features are remarkable about the deep waters in the Nansen, Amundsen and Canada basins: (1) a temperature minimum located about $800 \mathrm{~m}$ above the bottom $(1200 \mathrm{~m}$ in the Canada Basin) (2) and a slightly warmer, thick, 600-800 m, homogenous bottom layer (see Figs. 17-21). The increased temperature towards the bottom has been proposed to be caused by geothermal heating (Timmermanns et al., 2003; Björk and Winsor, 2006). That geothermal heating can influence the deeper layers is seen from stations taken close to subsurface volcano at the Gakkel Ridge (Fig. 20). The deep temperature minimum present elsewhere in the Eurasian Basin is here removed, and also the layers above the injection are warmer than at the surrounding stations. The warmer water had high concentration of manganese also indicating volcanic or thermal vent activities (Middag et al., 2011). A closer look at the deepest layers along the Gakkel Ridge also indicates a large variability of the deep waters with smaller-scale intrusions of anomalous water that likely is derived from the geothermal activity at the ridge (Fig. 20).

The Makarov Basin is different. Here no temperature minimum is present, and as the salinity becomes constant about $800 \mathrm{~m}$ above the bottom the temperature continues to decrease another $200 \mathrm{~m}$ (Fig. 21). This led Jones et al. (1995) 

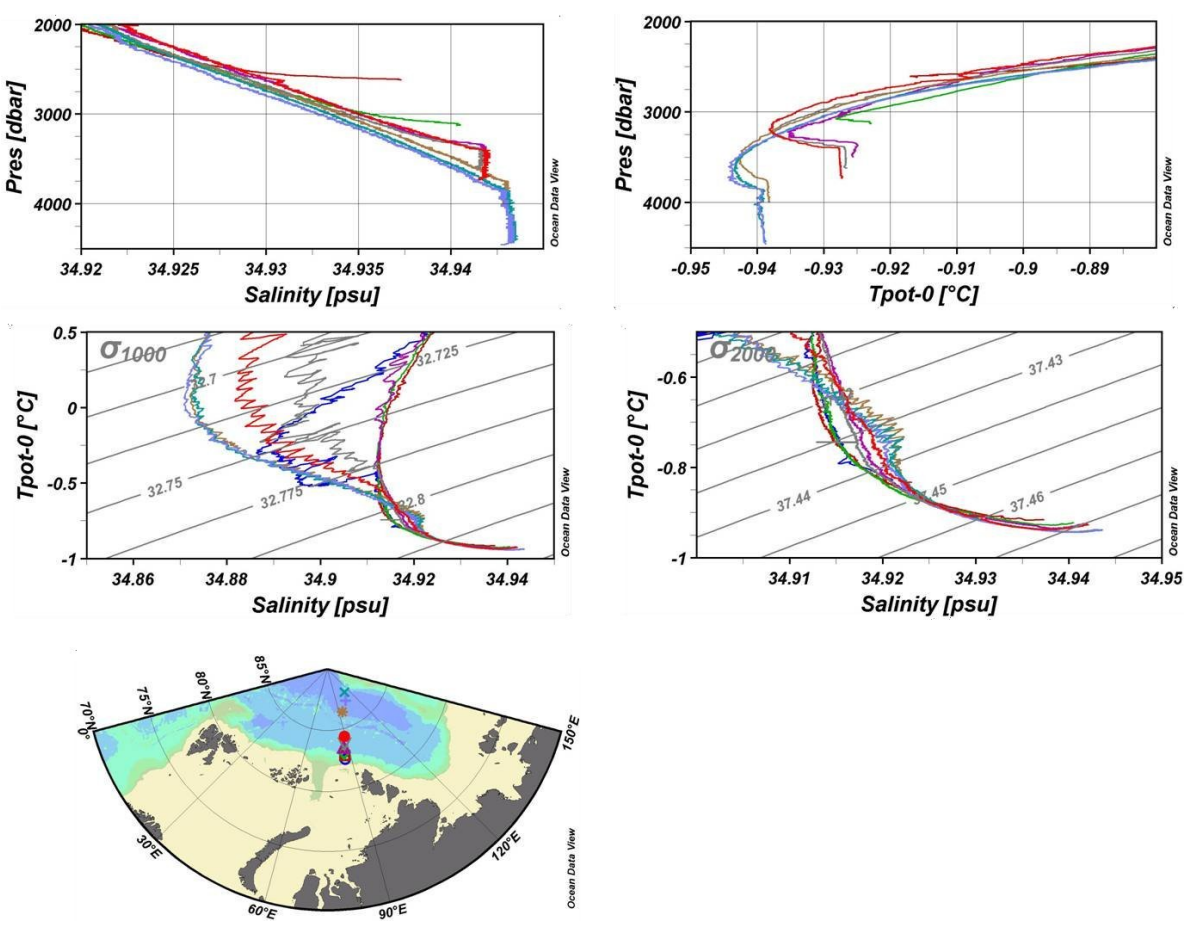

Fig. 18. Profiles of salinity and potential temperature and $\theta S$ curves showing the deep and bottom water in the Nansen and Amundsen basins along SPACE section 3. A deep temperature minimum and a homogenous bottom layer are present in both basins. The Amundsen Basin is deeper and its bottom water colder and more saline. In the $\theta S$ curves the less dense salinity minimum, found both at the slope (blue station) and in the interior, is derived from the Barents Sea inflow. The deep salinity maximum is observed in the Amundsen Basin and indicates an inflow of Amerasian Basin deep water across the Lomonosov Ridge.

to propose a spillover of deep Amundsen Basin water across the central part of the sill. In 2005, when Oden studied the area where such an overflow could occur, no flow from the Amundsen Basin to the Makarov Basin was observed. Instead the densest water at the sill was from the Makarov Basin, and a flow of Makarov Basin deep water into the Amundsen Basin was found (Björk et al., 2007). If a transport of deep water from the Amundsen Basin to the Makarov Basin takes place, this overflow must be intermittent (Rudels, 2012). Furthermore, the aluminium concentrations at middepth and deeper were higher in the Makarov Basin closer to the Lomonosov Ridge than in the rest of the basin and in the Canada Basin. Since the aluminium concentration is higher in the Amundsen Basin than in the Makarov Basin, this could be evidence of an input of deep water from the Amundsen Basin, which supports the idea of an intermittent flow across the ridge into the deep Makarov Basin (Middag et al., 2009).

The bottom water temperature has increased in the Makarov Basin, and some indications of a salinity increase are seen but the changes are very close to the observational accuracy (Fig. 21). If both a temperature rise and a salinity increase are seen, it could be due to advection and a gradual stronger presence of the warmer and more saline Canada Basin deep and bottom water in the absence of a spill-over of less saline Amundsen Basin deep water (Fig. 21).
A rough comparison between the Polarstern sections across the Eurasian Basin taken in 1996 and 2007 shows an increase in temperature in the bottom $1500 \mathrm{~m}$ by $0.025^{\circ} \mathrm{C}$, which, in a 1500-m-thick layer, corresponds to a heat flux of $\sim 445 \mathrm{~m} \mathrm{~W} \mathrm{~m}^{-2}$, which is more than 5 times larger than the average geothermal heat flux of $50-100 \mathrm{~m} \mathrm{~W} \mathrm{~m}^{-2}$ (Langseth et al., 1990) (Fig. 22). An additional heat source is then required. The fact that the salinity is increasing towards the bottom cannot be explained by geothermal heating, and slope convection must, at least intermittently, reach the deepest layers. Depending upon the characteristics of the ambient waters, which the descending plumes pass through, their final temperature will vary with time, and slope convection can thus also contribute to the observed heating of the lower layers. However, no significant increase in salinity is observed between the sections, suggesting weak deep reaching boundary convection during this period.

That shelf-slope convection can provide water dense enough to enter the deep Arctic Ocean has been observed in Storfjorden (e.g. Quadfasel et al., 1988), and also in the Arctic Ocean north of Severnaya Zemlya have saline, dense and warmer bottom layers been observed (Rudels et al., 2000a). In 2007 warmer, more saline and dense bottom layers were observed at the Kara and Laptev Sea slopes between 2500 m 

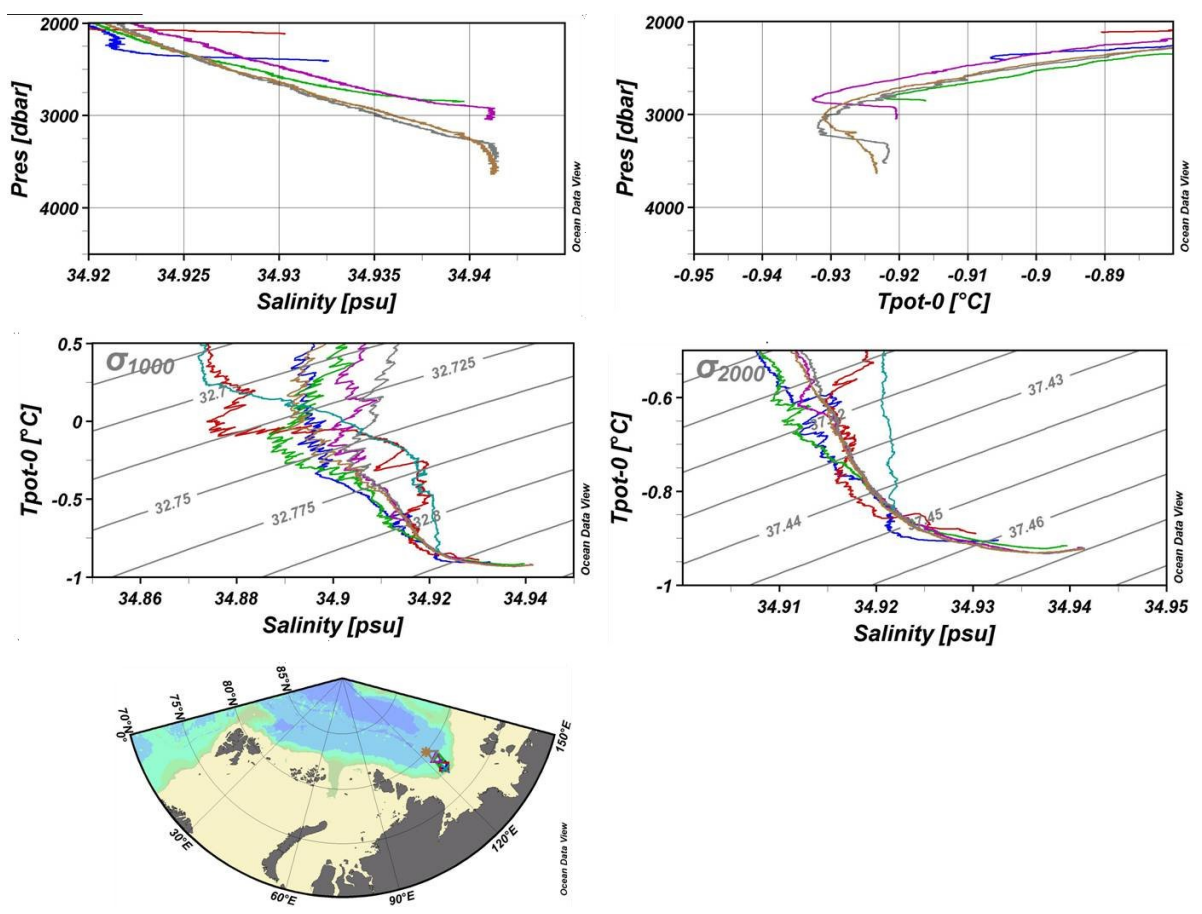

Fig. 19. Profiles of salinity and potential temperature, and $\theta S$ curves from SPACE section 4 north of the Laptev Sea. Here the slope of the deeper part of the $\theta S$ curves has become more perpendicular to the isopycnals, indicating both a salinity reduction due to the Barents Sea inflow and a deeper salinity increase due to slope convection and entraining, saline and dense plumes bringing heat and salt downwards. Bottom water with increasing temperature and salinity with depth are observed at the slope between $2000 \mathrm{~m}$ and $3500 \mathrm{~m}$ (blue, green and magenta stations).

and $3500 \mathrm{~m}$, indicating that dense plumes were present also in 2007 (Figs. 18 and 19).

On the Laptev Sea slope at the $2000 \mathrm{~m}$ isobath, an about 1000-m-thick, warm and saline layer was observed between $750 \mathrm{~m}$ and $1750 \mathrm{~m}$, almost reaching the bottom (Figs. 10 and 23). This layer, not present west of Severnaya Zemlya, could not be derived from the colder and less saline Barents Sea branch inflow, and a likely source is again the shelf area around Severnaya Zemlya. Fram Strait branch water could, by transient eddy motions or by meandering of the boundary current, be brought close to the slope. Saline water formed on the shelf would then interact with the warmer Fram Strait branch instead of passing through the cold, less saline Barents Sea branch water. The mixing and heating would lower the density of the plumes and remove the thermobaric effect, which promotes the sinking of colder plumes. Such a process could explain the observed warm, less dense characteristics and the fact that the water mass had already become detached from the bottom, perhaps eventually to form a thick, warm subsurface eddy.

That eddies are created is evident from observations both from the near surface layer as well as for the intermediate water range. Walsh et al. (2007) report of a deep (>1000 m) eddy found in historical data close to the Kara Sea slope, and on the SPACE cruise a 1000-m-thick eddy of almost undiluted Barents Sea branch characteristics was observed in the intra-basin in the central Lomonosov Ridge. How an eddy can survive such long advection is in itself an interesting question, but it shows that the Barents Sea branch water does reach the Lomonosov Ridge and then perhaps also the Makarov Basin through the different rifts in the ridge (Fig. 23).

\section{Summary}

The impact of the Barents Sea inflow branch on the Eurasian Basin and the interactions between the Barents Sea and the Fram Strait inflow branches have been examined. The meeting between the two branches leads to strong isopycnal mixing and to the creation of intrusive layers, not only north of the Kara Sea between the main Barents Sea branch inflow along the St. Anna Trough but also north of Franz Josef Land, where a smaller fraction of the Barents Sea inflow enters the Nansen Basin. The intrusions observed north of the Laptev Sea are similar to those found in the interior of the Nansen and Amundsen basins beyond the warm core of the Fram Strait branch. This indicates a turning of a large part of the boundary current within the Nansen Basin and a flow towards Fram Strait.

The temperature of the Atlantic layer in the Fram Strait branch stays fairly constant from Svalbard to Severnaya 

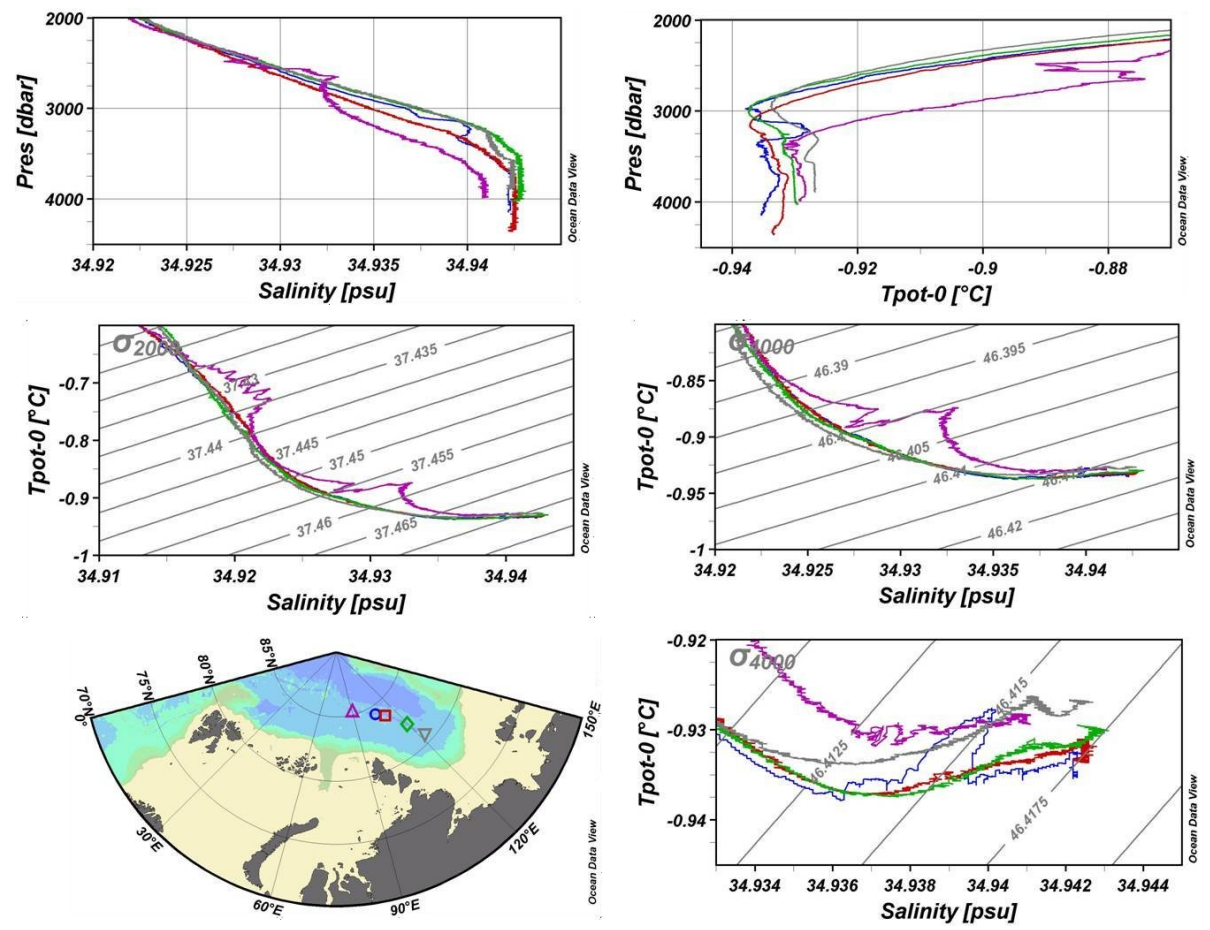

Fig. 20 . Profiles of salinity and potential temperature, and $\theta S$ curves shown with different blow-up levels from SPACE stations taken above the Gakkel Ridge. The simple deep water structure found in the basins is here disrupted by several different maxima and minima. A strong input of warmer and more saline water is found at $2700 \mathrm{~m}$ (magenta station), and a smaller deep intrusion is seen between $3100 \mathrm{~m}$ and $3300 \mathrm{~m}$ (blue station). The cause of these maxima could be geothermal activity at the ridge.
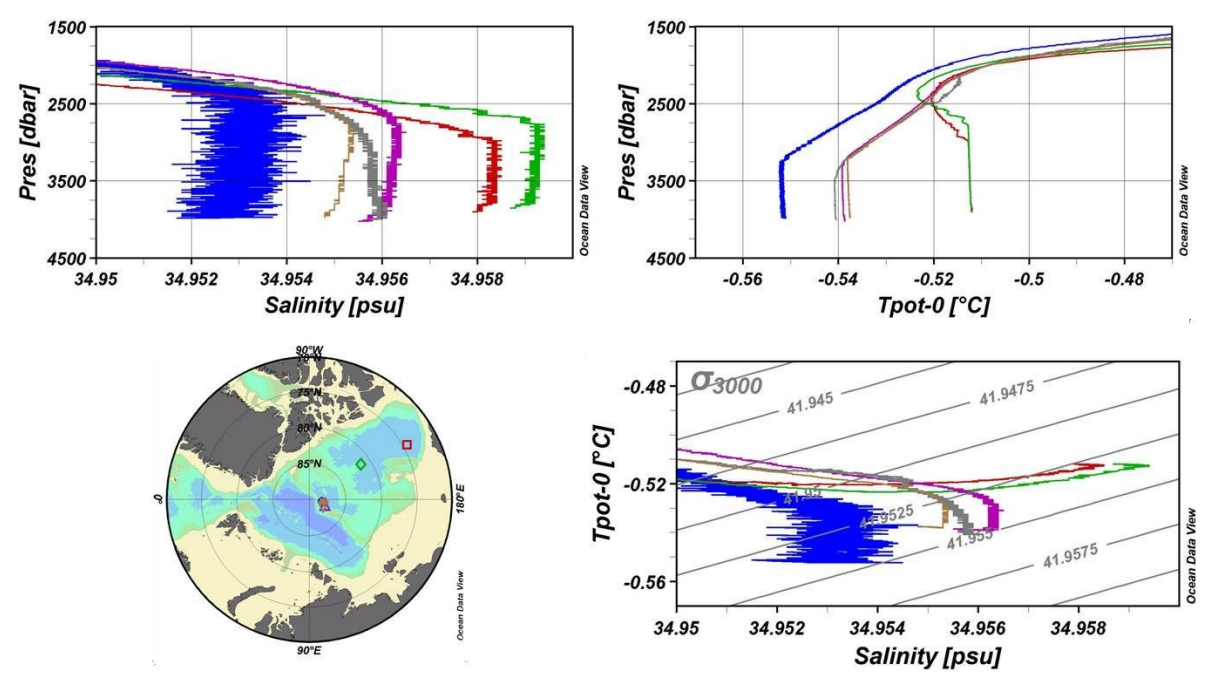

Fig. 21 . Profiles of salinity and potential temperature, and $\theta S$ curves from the Makarov Basin taken in 1991 (blue station), 2001 (grey station), 2005 (magenta station) and 2007 (brown station). The green and blue stations are from the southern (red) and northern (green) taken in 2005. The deep temperature minimum is absent in the Makarov Basin, but the Makarov Basin deep water could supply the temperature minimum of the Canada Basin, which is located at the same level as the sill depth of the Alpha and Mendeleev ridges. The temperature of the Makarov Basin bottom water has increased suggesting either heating or a temporary absence of colder deep water from the Amundsen Basin spilling over the ridge that otherwise would cool the deeper layers. The salinity in the bottom layer might be increasing with time, which would require some influx of the more saline Canada Basin deep water, not just geothermal heating. However, the observed salinity increase is not continuous in time and is very close to instrumental limitations. 

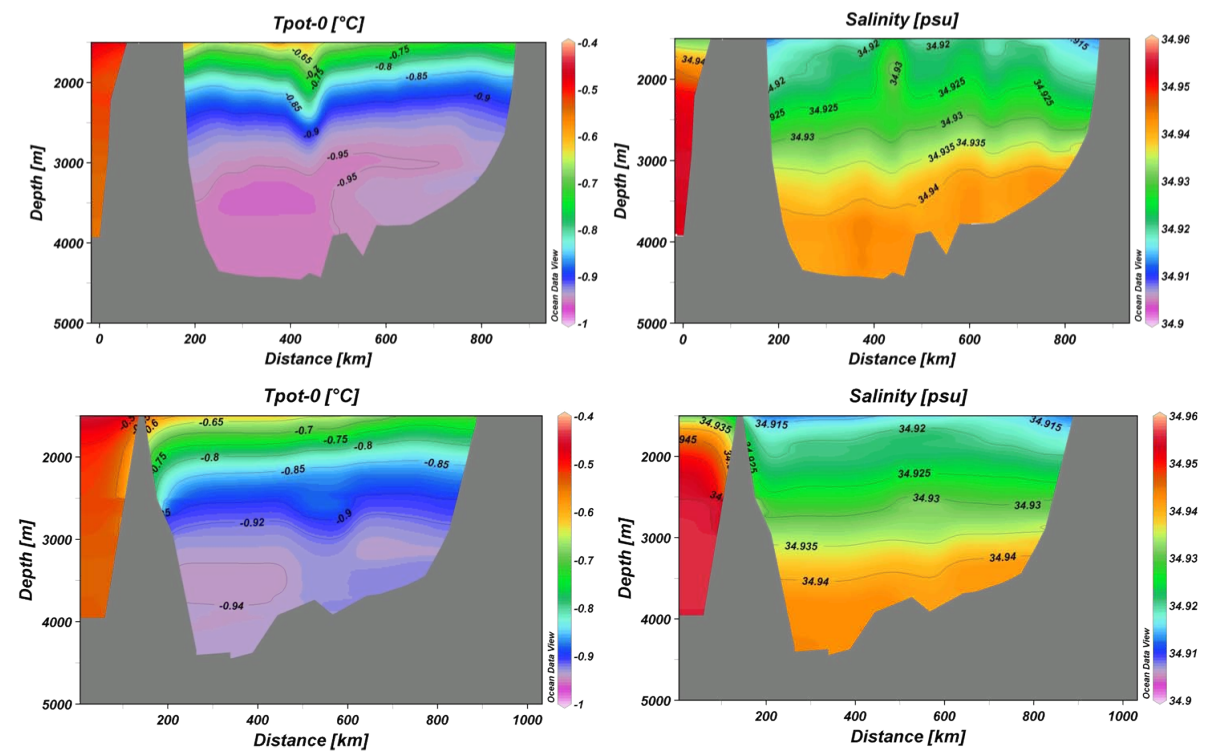

Fig. 22 . Potential temperature and salinity sections across the Eurasian Basin taken in 1996 (upper panel) and 2007 (lower panel.) showing the temperature increase, and a possible salinity decrease, below $1500 \mathrm{~m}$. The mean temperature difference is estimated at $0.015^{\circ} \mathrm{C}$.
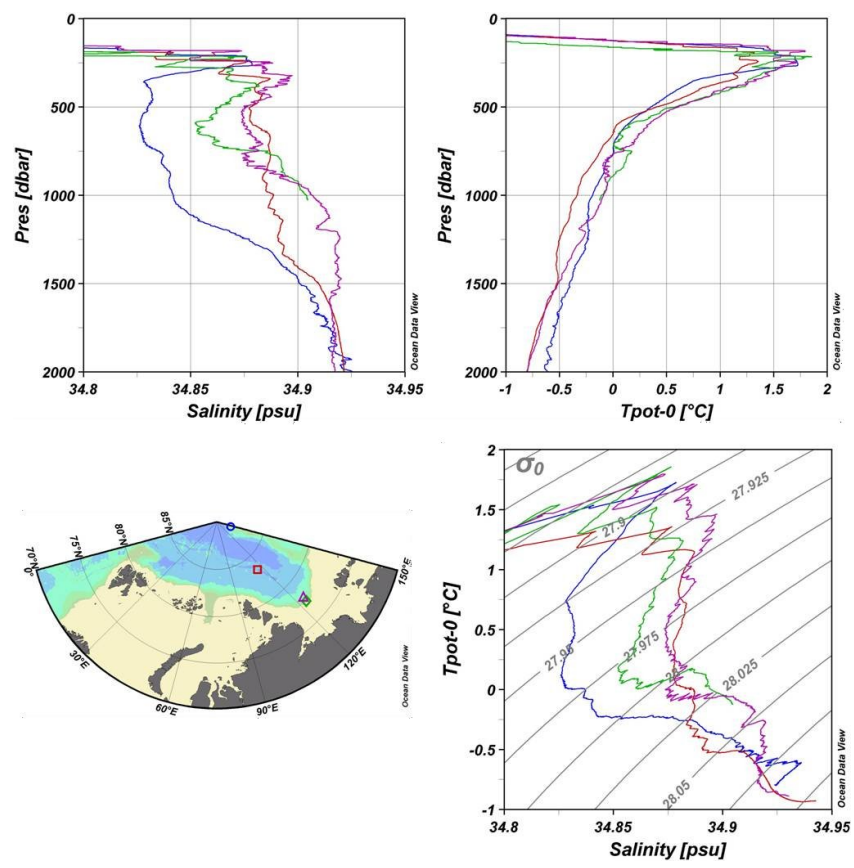

Fig. 23 . Profiles of salinity and potential temperature and $\theta S$ curves showing different eddies observed on the SPACE cruise 2007. Especially the 800 -m-thick eddy of Barents Sea branch water found in the intra-basin in the central Lomonosov Ridge (blue station) is remarkable.

Zemlya but then drops by $1{ }^{\circ} \mathrm{C}$ between the eastern Kara Sea and the Laptev Sea. This can (1) be explained by the cooling resulting from strong mixing between the inflow branches, but could (2) also be due to an extreme heat loss from the At- lantic layer north of Severnaya Zemlya. However, the lower temperatures could also be (3) an indication that a substantial fraction of the Fram Strait branch never penetrates across the Gakkel Ridge but returns towards Fram Strait, consistent with the existence of intrusions on the basin side of the Fram Strait branch. This is the interpretation favoured here.

The heat loss of the Atlantic water to the atmosphere and to sea ice seems to be confined to north of Svalbard and along the continental slope north of the Barents and Kara seas. Here warm Atlantic water comes close to the sea surface, and wind mixing as well as other mechanical mixing processes generated at the slope might increase the entrainment of Atlantic water and heat into the upper layer (Fig. 5).

The implication is that the Atlantic and intermediate waters in most parts of the Arctic Ocean are derived from the Barents Sea branch, not from the Fram Strait branch. The variations in temperature in the Atlantic layer in the Arctic Ocean should then be sought in the variability of the Barents Sea inflow, both at the Barents Sea Opening and by the atmospheric conditions over the Barents Sea, rather than in changes in the Atlantic water entering through Fram Strait. Only occasionally would the Fram Strait branch penetrate farther than the Nansen Basin to contribute to the changes in the Atlantic layer of the Arctic Ocean in the Amundsen Basin and beyond the Lomonosov Ridge.

The deeper layers in the Eurasian Basin have shown an increase in temperature of $0.025^{\circ} \mathrm{C}$ over the last $10 \mathrm{yr}$, which is more than 5 times that expected from geothermal heating. That geothermal heating can strongly influence the temperature profiles in the deeper layer was seen at stations taken close to a thermal vent in the Gakkel Ridge. Here the temperature minimum normally present above the homogenous 
$600-800 \mathrm{~m}$ thick bottom layer was absent. Slope convection can also contribute to the warming of the deeper layers, if slope plumes initially saline enough to enter the deeper layers are sinking through and entrain warmer water. Observations at the slope showed the presence of comparably warm and saline bottom layers at the Laptev Sea continental slope deeper than $2000 \mathrm{~m}$.

Higher up on the Laptev Sea slope, at $2000 \mathrm{~m}$, a 1000-mthick, warmer and more saline layer was observed between 750 and $1750 \mathrm{~m}$. This layer was not present at the eastern Kara Sea slope, which suggests that slope convection originating from around Severnaya Zemlya could have passed through warm Atlantic water, perhaps from the Fram Strait branch, and attained the higher temperature and salinity. This layer was less dense than the basin water column at the corresponding level and thus ready to detach from the slope, perhaps to form a warm intermediate water eddy.

Acknowledgements. Thanks are due to the Captains and Crews, who made these observations possible, and to the Scientists, whose remarks and insights are collected in this summary. R. Schlitzer's Ocean Data View has been used for the figures. Economic support has been given by the EU projects DAMOCLES (No. 018509) and THOR (No. 212643) and by the Academy of Finland (210551).

Edited by: K. J. Heywood

\section{References}

Aagaard, K. and Carmack, E. C.: The role of sea ice and other freshwater in the Arctic circulation, J. Geophys. Res., 94, 1448514498, 1989.

Aagaard, K. and Greisman, P.: Towards a new mass and heat budget for the Arctic Ocean, J. Geophys. Res., 80, 3821-3827, 1975.

Aagaard, K., Darnall, C., and Greisman, P.: Year-long measurements in the Greenland-Spitsbergen passage, Deep-Sea Res., 20, 743-746, 1973.

Aksenov, Y., Ivanov, V. V., Nurser, A. J. G., Bacon., S., Polykov, I. V., Coward, A. C., Naveira-Garabato, A. C., and BeszczynskaMöller, A.: The Arctic circumpolar boundary current, Geophys. Res., 116, C09017, doi:10.1029/2010JC006637, 2011.

Anderson, L. G., Jones, E. P., and Rudels, B.: Ventilation of the Arctic Ocean estimated from a plume entrainment model constrained by CFCs, J. Geophys. Res., 104, 13423-13429, 1999.

Beszczynska-Möller, A., Fahrbach, E., Schauer, U., and Hansen, E.: Variability in Atlantic water temperature and transport at the entrance of the Arctic Ocean 1997-2010, ICES J. Mar. Sci., 69, 852-863, doi:10.1093/icesjms/fss056, 2012.

Björk, G. and Winsor, P.: The deep waters of the Eurasian Basin, Arctic Ocean: geothermal heat flow, mixing and renewal, DeepSea Res. Pt. I, 53, 1253-1271, doi:10.1016/j.dsr.2006.05.006, 2006.

Björk, G., Jakobsson, M., Rudels, B., Swift, J. H., Anderson, L., Darby, D., Backman, J., Coakley, B., Winsor, P., Polyak, L., and Edwards, M.: Bathymetry and deep-water exchange across the Central Lomonosov Ridge at $88-89^{\circ}$ N, Deep-Sea Res. Pt. I, 54, 1197-1208, doi:10.1016/j.dsr.2007.05.010, 2008.
Blindheim, J.: Cascading of Barents Sea bottom water into the Norwegian Sea, edited by: Rapp. P.-V., Reun, Cons. Int. Explor. Mer, 188, 49-58, 1989.

Bourke, R. H., Weigel, A. M., and Paquette, R. G.: The westward turning branch of the West Spitsbergen Current, J. Geophys. Res. 93, 14065-14077, 1988.

Carmack, E. C., Macdonald, R. W., Perkin, R. G., and McLaughlin, F. A.: Evidence for warming of Atlantic water in the Southern Canadian Basin, Geophys. Res. Lett., 22, 1961-1964, 1995.

Carmack, E. C., Aagaard, K., Swift, J. H., Macdonald, R. W., McLaughlin, F. A., Jones, E. P., Perkin, R. G., Smith, J. N., Ellis, K. M., and Killius, L. R.: Changes in temperature and tracer distributions within the Arctic Ocean: results from the 1994 Arctic Ocean section, Deep-Sea Res. Pt. II, 44, 1487-1502, 1997.

Coachman, L. K. and Aagaard, K.: Physical Oceanography of the Arctic and Sub-Arctic Seas, in: Marine Geology and Oceanography of the Arctic Ocean, edited by: Herman, Y., Springer, New York, 1-72, 1974.

Dmitrenko, I., Timokhov, L., Andreev, O., Chadwell, R., Churkin, O., Dempsey, M., Kirillov, S., Smoliansky, V., Mastrukov, S., Nitishinskiy, M., Polyakov, I., Repina, I., Ringuette, M., Vetrov, A., and Walsh, D.: NABOSD-04 expedition on the Northern Laptev Sea aboard the icebreaker Kapitan Dranitsyn (September 2004), IARC Technical report 2, 113 pp., 2005.

Dmitrenko, I. A., Polyakov, I. V., Kirillov, S. A., Timokhov, L. A., Frolov, I. E., Sokolov, V. T., Simmons, H. L., Ivanov, V. V., and Walsh, D.: Towards a warmer Arctic Ocean: spreading of the early 21 st century Atlantic Water warm anomaly along the Eurasian Basin margins, J. Geophys. Res., 113, C05023, doi:10.1029/2007JC004158, 2007.

Falkner, K. K., Steele, M., Woodgate, R. A. Swift, J. H., Aagaard, K., and Morison, J.: Dissolved oxygen extrema in the Arctic Ocean halocline from the North Pole to the Lincoln Sea, DeepSea Res. Pt. I, 52, 1138-1154, 2005.

Fletcher, J. O.: The heat budget of the Arctic Basin and its relation to climate, The Rand Corporation R. 444-PR, Santa Monica, California, 179 pp., 1965.

Hátun, H., Sandø, A. B., Drange, H., Hansen, B., and Valdimarsson, H.: Influence of the Atlantic subpolar gyre on the thermohaline circulation, Science, 309, 1841-1844, 2005.

Holliday, N. P., Hughes, S. L., Bacon, S., Beszczynska-Möller, A., Hansen, B., Lavín, A., Loeng, H., Mork, K. A., Østerhus, S., Sherwin, T., and Walczowski, W.: Reversal of the 1960s to 1990s freshening trend in the northeast North Atlantic and Nordic Seas, Geophys. Res. Lett., 35, L03614, doi:10.1029/2007GL032675, 2008.

Hughes, S. L., Holliday, N. P., and Beszczynska-Möller, A. (Eds.): ICES Report on Ocean Climate 2010, ICES Cooperative Research Report, No. 309, International Council for the Exploration of the Sea, Copenhagen, 69 pp., 2011.

Ingvaldsen, R. B., Asplin, L., and Loeng, H.: Velocity field of the western entrance to the Barents Sea, J. Geophys. Res., 109, C03021, doi:10.1029/2003JC001811, 2004a.

Ingvaldsen, R. B., Asplin, L., and Loeng, H.: The seasonal cycle in the Atlantic transport to the Barents Sea during the years 19972001, Cont. Shelf Res., 24, 1015-1032, 2004b.

Jones, E. P., Rudels, B., and Anderson, L. G.: Deep waters of the Arctic Ocean: origins and circulation, Deep-Sea Res., 42, 737760, 1995. 
Karcher, M. J., Gerdes, R., Kauker, F., and Köberle, C.: Arctic warming - evolution and spreading of the 1990s warm event in the Nordic seas and in the Arctic Ocean, J. Geophys. Res., 108, 3034, doi:10.1029/2001JC001265, 2003.

Kikuchi, T., Inoue, J., and Morison, J.: Temperature differences across the Lomonosov Ridge: Implication for the Atlantic water circulation in the Arctic Ocean, Geophys. Res. Lett., 32, L20604, doi:10.1029/2005GL023982, 2005.

Korhonen, M., Rudels, B., Marnela, M., Wisotzki, A., and Zhao, J.: Time and space variability of freshwater content, heat content and seasonal ice melt in the Arctic Ocean from 1991 to 2011, Ocean Sci. Discuss., 9, 2621-2677, doi:10.5194/osd-92621-2012, 2012.

Kuzmina, N., Rudels. B., Zhurbas, V., and Stipa, T.: On the structure and dynamical features of intrusive layering in the Eurasian Basin in the Arctic Ocean, J. Geophys. Res., 116, C00D11, doi:10.1029/2010JC006920, 2011.

Langseth, M. G., Lachenbruch, A. H., and Marshall, B. V.: Geothermal observations in the Arctic region, in: The Geology of North America, edited by: Grantz, A., Johnson, L., and Sweeney, J. F., Geological Society of America, Boulder, CO, 133-151, 1990.

Loeng, H., Ozhigin, V., Ådlandsvik, B., and Sagen, H.: Current Measurements in the North- Eastern Barents Sea, ICES C. M., 1993/C:41, Hydrographic Committee, 22 pp., 1993.

Martin, S. and Cavalieri, D. J.: Contributions of the Siberian shelf polynyas to the Arctic Ocean intermediate and deep water, J. Geophys. Res., 94, 12725-12738, 1989.

McLaughlin, F. A., Carmack, E. C., Macdonald, R. W., and Bishop, J. K. B.: Physical and geo chemical properties across the Atlantic/Pacific water mass front in the Southern Canadian Basin, J. Geophys. Res., 101, 1183-1197, 1996.

Merryfield, W. J.: Intrusions in double-diffusively stable Arctic waters: evidence for differential mixing?, J. Phys. Oceanogr., 32, 1452-1459, 2002.

Middag, R., de Baar, H. J. W., Laan, P., and Bakker, K.: Dissolved aluminium and the silicon cycle in the Arctic Ocean, Mar. Chem., 115, 176-195, doi:10.1016/j.marchem.2009.08.002, 2009.

Middag, R., de Baar, H. J. W., Laan, P., and Klunder, M. B.: Fluvial and hydrothermal input of manganese into the Arctic Ocean, Geochim. Cosmochim. Ac., 75, 2393-2408, doi:10.1016/j.gca.2011.02.011, 2011.

Morison, J. H., Steele, M., and Anderson, R.: Hydrography of the upper Arctic Ocean measured form the nuclear submarine USS Pargo, Deep-Sea Res. Pt. I, 45, 15-38, 1998.

Nansen, F.: Oceanography of the North Polar Basin. The Norwegian North Polar Expedition 1893-1896, Scientific Results, 9, 427 pp., 1902.

Nansen, F.: Northern Waters, Captain Roald Amundsen's Oceanographic Observations in the Arctic Seas in 1901, VidenskabSelskabets Skrifter 1, Matematisk-Naturvidenskabelig Klasse 1, Kristiania, 1-145, 1906.

Nansen, F.: Spitsbergen Waters, Videnskabs-selskabets skrifter I. Matematisk-Naturvidenskabelig klasse I, 3, 145 pp., 1915.

Nikiferov, E. G. and Shpaiker, A. O.: Principles of large-scale variations of the Arctic Ocean hydrography, Hydrometeizdat, Leningrad, 269 pp., 1980.

Orvik, K. A. and Skagseth, Ø.: The impact of wind stress curl in the North Atlantic on the Atlantic inflow to the Norwegian Sea towards the Arctic, Geophys. Res. Lett., 30, 1884,
doi:10.1029/2003GL017932, 2003.

Polyakov, I. V., Beszczynska-Möller, A., Carmack, E.-C., Dmitrenko, I. A., Fahrbach, E., Frolov, I. F., Gerdes, R., Hansen, E., Holfort, J., Ivanov, V. V., Johnson, M. A., Karcher, M., Kauker, F., Morison, J., Orvik, K. A., Schauer, U., Simmons, H. L., Skagseth, Ø., Sokolov, V. T., Steele, M., and Timokhov, L. A.: One more step toward a warmer Arctic, Geophys. Res. Lett., 32, L17605, doi:10.1029/2005GL023740, 2005.

Polyakov, I. V., Alekseev, V. A., Ashik, I. M., Bacon, S., Beszczynska-Möller, A., Dmitrenko, I., Fortier, L., Gascard, J.C., Hansen, E., Hölemann, J., Ivanov, V. V., Kikuchi, T., Krillov, S., Lenn, Y.-D., Piechura, J., Repina, I., Timokhov, L. A., Walczowski, W., and Woodgate, R.: Fate of the early-2000s Arctic warm pulse, B. Am. Meteorol. Soc., 92, 561-566, 2011.

Quadfasel, D., Gascard, J.-C., and Koltermann, K. P.: Large-scale oceanography in Fram Strait during the 1984 Marginal Ice Zone experiment, J. Geophys. Res., 92, 6719-6728, 1987.

Quadfasel, D., Rudels, B., and Kurz, K.: Outflow of dense water from a Svalbard fjord into the Fram Strait, Deep-Sea Res., 35, 1143-1150, 1988.

Quadfasel, D., Sy, A., Wells, D., and Tunik, A.: Warming in the Arctic, Nature, 350, p. 385, 1991.

Quadfasel, D., Rudels, B., and Selchow, S.: The Central Bank vortex in the Barents Sea: water mass transformation and circulation, ICES Mar. Sc., 195, 40-51, 1992.

Rudels, B.: The $\theta S$ relations in the northern seas: implications for the deep circulation, Polar Res., 4, 133-159, 1986.

Rudels, B.: On the mass balance of the Polar Ocean, with special emphasis on the Fram Strait, Norsk Polarinst, Skrifter, 188, 53 pp., 1987.

Rudels, B.: Arctic Ocean circulation and variability - advection and external forcing encounter constraints and local processes, Ocean Sci., 8, 261-286, doi:10.5194/os-8-261-2012, 2012.

Rudels, B. and Friedrich, H. J.: The transformations of Atlantic water in the Arctic Ocean and their significance for the freshwater budget, in: The Freshwater Budget of the Arctic Ocean, edited by: Lewis, E. L., Jones, E. P., Lemke, P, and Prowse, T., NATO Science Series 2, Environmental Security, Kluwer Academic Publishers, Dordrecht, 70, 503-532, 2000.

Rudels, B., Jones, E. P., Anderson, L. G., and Kattner, G.: On the intermediate depth waters of the Arctic Ocean, in: The Role of the Polar Oceans in Shaping the Global Climate, edited by: Johannessen, O. M., Muench, R. D., and Overland, J. E., American Geophysical Union, Washington, D.C., 33-46, 1994.

Rudels, B., Anderson, L. G., and Jones, E. P.: Formation and evolution of the surface mixed layer and the halocline of the Arctic Ocean, J. Geophys. Res., 101, 8807-8821, 1996.

Rudels, B., Muench, R. D., Gunn, J. Schauer, U., and Friedrich, H. J.: Evolution of the Arctic Ocean boundary current north of the Siberian shelves, J. Marine Syst., 25, 77-99, 2000a.

Rudels, B., Meyer, R., Fahrbach, E., Ivanov, V. V., Østerhus, S., Quadfasel, D., Schauer, U., Tverberg, V., and Woodgate, R. A.: Water mass distribution in Fram Strait and over the Yermak Plateau in summer 1997, Ann. Geophys., 18, 687-705, doi:10.1007/s00585-000-0687-5, 2000b.

Rudels, B., Jones, E. P., Schauer, U., and Eriksson, P.: Atlantic sources of the Arctic Ocean surface and halocline waters, Polar Res., 23, 181-208, 2004. 
Rudels, B., Marnela, M., and Eriksson, P.: Constraints on estimating mass, heat and freshwater transports in the Arctic Ocean - an exercise, in: Arctic-Subarctic Ocean Fluxes, edited by: Dickson, R. R., Meincke, J., and Rhines, P., Springer, Dordrecht, 315-341, 2008.

Rudels, B., Kuzmina, N., Schauer, U., Stipa, T., and Zhurbas, V.: Double-diffusive convection in the Arctic Ocean - distribution and importance, Geophysica, 45, 199-213, 2009.

Rudels, B., Anderson, L.G., Eriksson, P., Fahrbach, E., Jakobsson, M., Jones, E.P., Melling, H., Prinsenberg, S., Schauer, U., and Yao, T.: Observations in the Ocean, in Arctic Climate Change - The ACSYS Decade and Beyond, edited by: Lemke, P. and Jacobi, H.-W., Springer, Heidelberg, 117-198, 2012.

Schauer, U. and Beszczynska-Möller, A.: Problems with estimation and interpretation of oceanic heat transport - conceptual remarks for the case of Fram Strait in the Arctic Ocean, Ocean Sci., 5, 487-494, doi:10.5194/os-5-487-2009, 2009.

Schauer, U., Muench, R. D. Rudels, B., and Timokhov, L.: Impact of Eastern Arctic shelf water on the Nansen Basin intermediate layers, J. Geophys. Res., 102, 3371-3382, 1997.

Schauer, U., Loeng, H., Rudels, B., Ozhigin, V. K., and Dieck, W.: Atlantic Water flow through the Barents and Kara Seas, DeepSea Res. Pt. I, 49, 2281-2298, 2002a.

Schauer, U., Rudels, B., Jones, E. P., Anderson, L. G., Muench, R. D., Björk, G., Swift, J. H., Ivanov, V., and Larsson, A.-M.: Confluence and redistribution of Atlantic water in the Nansen, Amundsen and Makarov basins, Ann. Geophys., 20, 257-273, doi:10.5194/angeo-20-257-2002, 2002b.

Schauer, U., Fahrbach, E., Østerhus, S., and Rohardt, G.: Arctic Warming through the Fram Strait: oceanic heat transports from 3 years of measurements, J. Geophys. Res., 109, C06026, doi:10.1029/2003JC001823, 2004.

Schauer, U., Beszczynska-Möller, A., Walczowski, W., Fahrbach, E., Piechura, J., and Hansen, E.: Variation of measured heat flow through the Fram Strait between 1997-2006, in: ArcticSubarctic Ocean Fluxes, edited by: Dickson, R. R., Meincke, J., and Rhines, P., Springer, Dordrecht, 65-85, 2008.
Schlitzer, R.: Ocean Data View, available at: http://odv.awi.de, 2012.

Shimada, K., McLaughlin, F. A., Carmack, E. C., Proshutinsky, A., Nishino, S., and Itoh, M.: Penetration of the 1990s warm temperature anomaly of the Atlantic Water in the Canada Basin, Geophys. Res. Lett., 31, L20301, doi:10.1029/2004GL020860, 2004.

Skagseth, Ø., Furevik, T., Ingvaldsen, R., Loeng, H., Mork., K. A., Orvik, K. A., and Ozhigin, V.: Volume and heat transports to the Arctic Ocean via the Norwegian and Barents seas, in: ArcticSubarctic Ocean Fluxes, edited by: Dickson, R. R., Meincke, J., and Rhines, P., Springer, Dordrecht, 45-64, 2008.

Skagseth, Ø., Drinkwater, K. F., and Terrile, E.: Wind- and buoyancy-induced transport of the Norwegian coastal current in the Barents Sea, J. Geophys. Res., 116, C08007,5 doi:10.1029/2011JC006996, 2011.

Steele, M. and Boyd, T.: Retreat of the cold halocline layer in the Arctic Ocean, J. Geophys. Res., 103, 10419-10435, 1998.

Swift, J. H., Jones, E. P., Carmack, E. C., Hingston, M., Macdonald, R. W., McLaughlin, F. A., and Perkin. R. G.: Waters of the Makarov and Canada Basins, Deep-Sea Res. Pt. II, 44, 15031529, 1997.

Timmermanns, M.-L., Garrett, C., and Carmack, E.: The thermohaline structure and evolution of the deep waters in the Canada Basin, Arctic Ocean, Deep-Sea Res. Pt. I, 50, 13051321, doi:10.1016/S0967-0637(03)00125-0, 2003.

Walsh, D. and Carmack, E.: The nested structure of Arctic thermohaline intrusions, Ocean Model., 5, 267-289, 2003.

Walsh, D., Polyakov, I, Timokhov, L., and Carmack, E.: Thermohaline structure and variability in the eastern Nansen Basin as seen from historical data, J. Mar. Res., 65, 685-7144, 2007.

Woodgate, R. A., Aagaard, K., Muench, R. D., Gunn, J., Björk, G., Rudels, B., Roach, A. T., and Schauer, U.: The Arctic Ocean boundary current along the Eurasian slope and the adjacent Lomonosov Ridge: water mass properties, transports and transformations from moored instruments, Deep-Sea Res. Pt. 1, 48, 1757-1792, 2001. 